Acta Botanica Brasilica - 30(1): 60-77. January-March 2016.

(C)2016 doi: 10.1590/0102-33062015abb0247

\title{
Selaginella P. Beauv. from Minas Gerais, Brazil
}

\author{
Gustavo Heringer', Iván A. Valdespino² and Alexandre Salino ${ }^{3^{*}}$
}

Received: September 21, 2015

Accepted: October 23, 2015

\begin{abstract}
Selaginella P. Beauv. is the only genus in the family Selaginellaceae Willk. The genus is monophyletic, has a cosmopolitan distribution, contains about 750 species and can be characterized by the presence of rhizophores, leaves, a ligule, heterospory and adaxial, reniform sporangia. Twenty species were found in the study area: Selaginella alstonii, S. contigua, S. convoluta, S. decomposita, S. erectifolia, S. erythropus, S. flexuosa, S. jungermannioides, S. macrostachya, S. marginata, S. microphylla, S. muscosa, S. producta, S. sellowii, S. sematophylla, S. suavis, S. sulcata, S. tenella, S. tenuissima and S. vestiens. Two new species records for the state are presented (S. jungermannioides and $S$. tenella). We present descriptions of the genus and species, an identification key, the synonyms pertaining to Brazil, illustrations, and comments about the taxonomy and distribution of species in Brazil.
\end{abstract}

Keywords: Lycophytes, pteridophytes, Selaginellaceae, Southeastern Brazil, taxonomy

\section{Introduction}

Selaginella is the only genus in the family Selaginellaceae, has a fossil record that dates back from the late Carboniferous (Rowe 1988; Thomas 2005) and is placed in the division Lycopodiophyta (Pryer et al. 2001; Banks 2009). The family is clearly monophyletic and is sister to Isoetaceae (Korall et al. 1999; Pryer et al. 2001; Korall \& Kenrick 2002; Pryer et al. 2004).

The genus is characterized by the presence of rhizophores, leaves, a ligule, heterospory and adaxial, reniform sporangia (Webster 1992). The genus has a cosmopolitan distribution (Tryon \& Tryon 1982; Jermy 1986; 1990) and comprises approximately 750 species (Góes-Neto et al. 2015), of which circa 270 species are found in the Americas (Tryon \& Tryon 1982) and 61 occur in Brazil (Valdespino et al. 2015).

Various works exist about the infrageneric classification of Selaginella (e. g. Spring 1849; Baker 1883; Walton \& Alston 1938; Alston et al. 1981; Jermy 1986; 1990). The most recent classifications (Jermy 1986; 1990) divide Selaginella into five subgenera based on morphology and geographic distribution. Since then phylogenetic studies based on molecular characters have suggested that some of these subgenera may not be monophyletic (Korall et al. 1999; Korall \& Kenrick 2002). Furthermore, Korall \& Kenrick (2004) as well as the previously mentioned studies have suggested the infrageneric division of Selaginella into two groups: one group representing $S$. selaginoides (subg. Selaginella) and another group, with the majority of the species, called the "rhizophoric clade" by Korall \& Kenrick (2002).

The main studies about species of Selaginella from Brazil are the following: Spring (1840), Fée (1869; 1873), Alston (1936), Alston et al. (1981); and in a reginal scale: Silveira (1898; 1908), Bautista (1974a; 1974b), Bautista et al. (1975), Castellani \& Freitas (1992), Hirai \& Prado (2000), Prado \& Freitas (2005), Hirai (2007), and Prado \& Hirai (2008). Still, new species have been recently described (Valdespino et al. 2015; Góes-Neto et al. 2015) and the new records in this work show that taxonomic and floristic studies can significantly increase our knowledge about the genus. Therefore, our objective in this study was to develop a taxonomic treatment of Selaginella for the state of Minas Gerais, Brazil.

\footnotetext{
${ }^{1}$ Departamento de Biologia Vegetal, Universidade Federal de Viçosa, P.H. Rolfs, 36570-900, Viçosa, MG, Brazil

${ }^{2}$ Departamento de Botánica, Facultad de Ciencias Naturales, Exactas y Tecnología, Universidad de Panamá, Apartado Postal 0824-00073, Panamá, Panama

${ }^{3}$ Departamento de Botânica, Instituto de Ciências Biológicas, Universidade Federal de Minas Gerais, P.O. Box 486, 31270-901, Belo Horizonte, MG, Brazil

* Corresponding author: salinobh@gmail.com
} 


\section{Materials and methods}

The taxonomic study was based on samples collected by a team of pteridologists from UFMG, which were processed according to standard techniques and deposited at BHCB. In addition, herbarium specimens from Brazilian (CESJ, HUFU, OUPR, R, RB, SP and SPF) and foreign herbaria (B, BM, C, F, K, NY and P) with important historial and type specimens, including digitized images, were studied. The herbarium abbreviations used in this work are based on Index Herbariorum (Thiers 2015).

The genus description was based on Tryon \& Tryon (1982), Tryon \& Stolze (1994), Fraile et al. (1995) and Mickel et al. (2004). Species descriptions were based on selected material and field observations. Measurements of leaves were made following Valdespino et al. (2014), whereas those of stems diameter were taken below the first branch and of the width of terminal branches on sterile branches (including leaves). Spore color given are based on observation under a dissecting scope with an incident yellow light at 6.7-80.0 magnification and taking care that these were not contaminated by debris or fungi. The terms employed in this work are based on those used by Lellinger (2002), except for carinate (Stearn 1992) and isophyllous and anisophyllous (Mickel et al. 2004). Additionally, we prefer to follow Mital (1969) and Valdespino (1995) as explained in Valdespino et al. (2014) in terming leaves surfaces as "upper" (in lateral leaves = adaxial, while in median leaves = abaxial) and "lower" (in lateral leaves = abaxial, whereas in median leaves $=$ adaxial).
Moreover, to keep descriptions manageable, the presence of idioblasts and other projections on leaf surfaces is only mentioned for those species where they are found. We present the discrepant morphological measures between parentheses to highlight the exception.

\section{Results and discussion}

Selaginella P. Beauv., Mag. Encycl. 5: 478. 1804; and Prod. Fam. Aethéog. p. 101. 1805, nom. cons.

Type: Selaginella spinosa P. Beauv. nom. nov. for Lycopodium selaginoides L. [三Selaginella selaginoides (L.) Link].

Plants terrestrial, rupicolous or rarely epiphytic. Stem thin, branched, sometimes dichotomously, prostrate, creeping, ascending or erect, usually arising from a stoloniferous base, with numerous leaves. Leaves isophyllous, generally imbricate or anisophyllous, alternating in four rows, two ventral and not appressed to the stem and two dorsally appressed, axillary leaves present on stem branches. Sporangia wide, originating in the axils of sporophylls. Megasporangia deltate-ovoid to lobed, usually containing four megaspores. Microsporangia ovoid, containing numerous microspores. Megaspores large (ca. 150-1500 $\mu \mathrm{m}$ ), tetrahedral-globose, trilete, often with an equatorial flange, surface, regulate, reticulate, rugulatereticulate, papillate, tuberculate, granulate or seemingly smooth on the proximal surface. Microspores small (ca. 18-63 $\mu \mathrm{m}$ ), tetrahedral-globose, trilete, often with an equatorial flange, finely to coursely echinulate, rugulate, papillate, perforate-cristate or granulate.

\section{Key to the species of Selaginella that occur in Minas Gerais}

1- Leaves acicular, isophyllous throughout stem, spiral 14. S. sellowii

1'- Leaves not acicular, anisophyllous at least on upper $1 / 2$ of stem, not spiral

2- Stem articulate; rhizophores dorsal, rarely dorsal and ventral on same bifurcation; megasporophylls at base of strobilus ca. two times longer than microsporophylls

3- Stem with only one vascular bundle; leaves peltate 10. S. marginata

3'- Stem with two vascular bundles; leaves basifixed laterally and axillary

4- Axillary leaves biauriculate; lateral leaves biauriculate, with a long, acroscopic auricle 17. S. sulcata

4'- Axillary leaves not auriculate; lateral leaves with a small, basiscopic auricle 16. S. suavis

2'- Stem not articulate; rhizophores ventral or axillary, rarely dorsal and ventral on same bifurcation; megasporophylls as long as microsporophylls

5- Plants forming a rosette; branches enrolled inward when dry; lateral leaves peltate 3. S. convoluta

5'- Plants not forming a rosette; branches rarely enrolled inward when dry; lateral leaves basifixed

6- Axillary and lateral leaves with short- to long-ciliate margins, on at least lower $1 / 2$; when short-ciliate, axillary leaves never oblong to oblong-obovate

7- Plants basally isophyllous, becoming anisophyllous near first branch, stoloniferous

8- Plants generally larger than $10 \mathrm{~cm}$; stem generally reddish at base; lateral leaves generally falcate

8'- Plants smaller than $10 \mathrm{~cm}$; stem never reddish at base; lateral leaves never falcate 6. S. erythropus

7'- Plants anisophyllous throughout stem, never stoloniferous 20. S. vestiens

9- Plants erect to ascending, rarely prostrate; dorsal leaves apically aristate 
10- Rhizophores generally on lower $\frac{1}{2}$ of stem; sterile terminal branches more than $5.4 \mathrm{~mm}$ wide; lateral leaves slightly ascending to patent, long-oblong, rarely oblong-lanceolate

2. S. contigua

10'- Rhizophores generally throughout stem; sterile terminal branches less than $5.1 \mathrm{~mm}$ wide; lateral leaves slightly reflexed to patent, ovate-lanceolate to ovate

9. S. macrostachya

9'- Plants prostrate; dorsal leaves with acute, short-acuminate or cuspidate apex

11- Lateral leaves ascending, recurved, frequently adpressed to stem

11. S. microphylla

11'- Lateral leaves patent, not recurved, not adpressed to stem

12- Dorsal leaves with idioblasts in the upper surface, apex acute

15. S. sematophylla

12'- Dorsal leaves without idioblasts in the upper surface, apex acuminate to long-acuminate

8. S. jungermannioides

6'- Axillary and lateral leaves with entire to serrate margins on lower $1 / 2$, rarely short-ciliate, then with axillary leaves oblong to oblong-obovate

13- Plants stoloniferous, apex generally radicant

18. S. tenella

13'- Plants not stoloniferous, apex not radicant

14- Plants erect with upper surface of leaves smooth, without idioblasts; rhizophores on lower $1 / 2$ of stem, rarely on upper $1 / 2$; lateral leaves ascending to slightly ascending

15- Lateral leaves less than $1.0 \mathrm{~mm}$ apart (below first branch); apex of dorsal leaves acuminate to shortaristate (arista less than $1 / 3$ of leaf), not dorsally serrate; sterile terminal branch generally less than $2.0 \mathrm{~mm}$ wide (including leaves)

5. S. erectifolia

15'- Lateral leaves more than $1.2 \mathrm{~mm}$ apart (below first branch); apex of dorsal leaves long-aristate (arista more than $1 / 3$ of leaf), dorsally serrate; sterile terminal branch more than $2.1 \mathrm{~mm}$ wide (including leaves) ......

4. S. decomposita

14'- Plants prostrate to ascending, if erect upper surface of leaves rugose or with idioblasts; rhizophores throughout stem; lateral leaves patent, rarely slightly reflexed or slightly ascending

16- Lateral leaves ovate, ovate-lanceolate to widely elliptic; dorsal leaves ovate, ovate-elliptic to cordiform

17- Leaves with idioblasts on the upper surface; lateral leaves with acute apex; axillary leaves ovate to ovate-lanceolate

12. S. muscosa

17'- Leaves without idioblasts on the upper surface; lateral leaves with obtuse to rounded apex; axillary

leaves oblong, rarely oblong-obovate

19. S. tenuissima

16'- Lateral leaves oblong, oblong-lanceolate to ovate-oblong; dorsal leaves elliptic, rarely lanceolate

18- Plants frequently vinaceous; dorsal leaves with conspicuous idioblasts in the upper surface

13. S. producta

18'- Plants green; dorsal leaves without idioblasts in the upper surface

19- Lateral and axillary leaves flat, never forming a longitudinal depression over the vein; dorsal leaves with aristate to long-aristate apex; leaves with rugose upper surface

7. S. flexuosa

19'- Lateral and axillary leaves generally forming longitudinal depression over the vein; dorsal leaves with acuminate (or rarely short-aristate) apex; leaves with smooth upper surface

1. S. alstonii

1. Selaginella alstonii G. Heringer, Salino \& Valdespino Phytokeys. 50: 51. 2015.

\section{Fig. 1A-D}

Stem prostrate to ascending, greenish to stramineous, to $10 \mathrm{~cm}$ long, not articulate, not stoloniferous, pale to green, 0.3-0.6 mm diam., vascular bundle one; sterile terminal branch 1.5-3.1 mm wide, 2-3 pinnate. Rhizophores ventral, borne on the proximal $2 / 3$, pale. Leaves anisophyllous throughout stem. Lateral leaves $1.1-2.0 \mathrm{x}$ 0.4-1.0 mm, patent to slightly ascending, basifixed, oblong, rarely oblong-lanceolate, generally forming a longitudinal depression over the vein, base slightly rounded on acroscopic side, acroscopic margin serrate, rarely short-ciliate, basiscopic margin entire to serrate, hyaline to light green acroscopically, with elongate, translucent cells, apex acute, rarely cuspidate, chloroplasts evident to slightly evident, upper surface smooth, without idioblasts. Axillary leaves similar to the lateral leaves, but $0.9-1.7 \times 0.4-0.7 \mathrm{~mm}$, margins serrate to short-ciliate in the proximal $1 / 4$. Dorsal leaves $0.7-1.4 \times 0.4-0.7 \mathrm{~mm}$, basifixed, elliptic to ellipticlanceolate, bases oblique, margins serrate, hyaline to light green on upper surface, with elongate, translucent cells, apex acuminate, rarely short-aristate, inner margin serrate to short-ciliate, outer margin entire to serrate or shortciliate, chloroplasts evident to slightly evident, upper surface smooth, without idioblasts. Strobilus to $5.1 \mathrm{~mm}$ long, dorsal sporophylls shorter than ventral sporophylls. Dorsal sporophylls strongly ascending, carinate, carina not serrate, ovate to ovate-lanceolate, with serrate margins, hyaline to light green, with elongate cells, apex acute to acuminate, chlorophyll present, upper surface without idioblasts, smaller than ventral sporophylls. Ventral sporophylls strongly ascending, carinate, ovate, margins ser- 
rate, hyaline to obscurely light green, with elongate cells, apex acute to acuminate, chlorophyll present. Megaspores cream to yellowish. Microspores orangish.

Distribution and habitat: Endemic to the region of Pico do Itambé, in Serra do Espinhaço (Minas Gerais, Brazil), were it is rupicolous in campo rupestre and on rocky caves. Specimens examined: BRAZIL. Minas Gerais: Santo Antônio do Itambé, Parque Estadual do Pico do Itambé, 5/X/2006, T.E. Almeida et al. 533 (BHCB, PMA); Idem, Parque Estadual do Pico do Itambé, 5/X/2006, T.E. Almeida et al. 535 (BHCB).

Comments: Selaginella alstonii is characterized by its prostrate to ascending habit, and dorsal leaves with an acuminate apex (rarely aristate). Among the species that occur in Minas Gerais, Selaginella decomposita is the most similar but this species tends to be larger and has an erect habit (vs. ascending to prostrate), lateral and dorsal leaves without a longitudinal groove, and dorsal leaves that are long-aristate to long-attenuate.

2. Selaginella contigua Baker, J. Bot., Lond. 22: 295. 1884. Lectotype (chosen by Hirai \& Prado, 2000: 318): Brazil, Rio de Janeiro, A.F.M. Glaziou 5638 (K-image! [K000589195]; isolectotypes: BM not seen, B-image! [B200129413], C!, P! [P00044886]).

Selaginella callimorpha Silveira, Bol. Commiss. Geogr. Geol. Minas Geraes 5: 121. 1898. Type: Brazil, Minas Gerais, Serra do Chora (Mantiqueira), entre Serra de Ibitipoca e Rio Preto, V/1898, H. Magalhães s.n.; n. 275 in herb. Com. Geog. et Geol. Civitatis Minas Geraes (holotype: not located; possible isotype: B-image! [B200129416 e]).

Selaginella wettsteinii Hieron., Denkschr. Kaiserl. Akad. Wiss. Wien. Math.-Naturwiss. Kl. 79(1): 60. 1908. Type: Brazil, São Paulo. In silvis ad "Brasso" grande in districtu urbis Itapecirica, ca. 1000 m. s. m., Jun 1901, Wettstein \& Schiffner s.n. (holotype: B-image! [B200129713]; isotype: WU-image! [WU0031759]).

\section{Fig. 1E-G}

Stem erect, greenish, to $42 \mathrm{~cm}$ long, 0.8-1.9 $\mathrm{mm}$ diam., vascular bundle one; terminal branch 5.4-10.9 mm wide. Rhizophores ventral, rarely ventral and dorsal on the same bifurcation, present on lower $1 / 2$ of stem, rarely on upper $1 / 2$. Leaves anisophyllous. Lateral leaves $2.4-6.5 \mathrm{x}$ 0.9-2.5 mm, slightly ascending to patent, basifixed, longoblong, rarely oblong-lanceolate, base rounded to cordate acroscopically, margins ciliate to serrate, apex acute to obtuse, upper surface rugose. Axillary leaves similar to de lateral leaves, but 2.6-4.6 x 1.1-2.3 mm. Dorsal leaves 1.9-3.7 x 0.8-2.1 mm, basifixed, elliptic to ovate, base rounded to rarely cordate, margins ciliate, with translucent, elongate cells, apex long-aristate, arista ca. $1 / 3$ the length of the leaf, serrate on the margins, upper surface rugose. Strobilus to $31.3 \mathrm{~mm}$ long, dorsal and ventral sporophylls equal in length. Dorsal sporophylls carinate, carina generally serrate, at least near apex, lanceolate to ovate-lanceolate, with serrate margins. Ventral sporophylls carinate, lanceolate to ovate-lanceolate, with serrate margins. Megaspores cream. Microspores orangish. Distribution and habitat: Southeastern and southern Brazil (Minas Gerais, Espírito Santo, Rio de Janeiro, São Paulo, Paraná and Santa Catarina), where it grows in evergreen and semi-deciduous forest.

Specimens examined: BRAZIL. Minas Gerais: Mariana, 5/XI/1984, J. Badini s.n. pro parte (cultivada) (OUPR 12039); Santa Bárbara do Monte Verde, Serra Negra Fazenda Três Cruzes, 21/IV/2004, J.P.S. Condack 100 (RB). Additional selected specimens examined: BRAZIL. Rio de Janeiro: Itatiaia, 10/VII/1879, A.F.M. Glaziou 5638 (C); São Paulo: Ubatuba, Parque Estadual da Serra do Mar, 7/VIII/2001, A. Salino et al. 7325 (BHCB).

Comments: Selaginella contigua is characterized by having leaves that are basally ciliate to long-ciliate, lateral leaves oblong to oblong-lanceolate and dorsal leaves with aristate apices. Among the most similar species encountered, Selaginella macrostachya can be differentiated by its lateral leaves that are generally reflexed and ovate to ovate-oblong. Selaginella contigua differs from $S$. mendoncae by having dorsal leaves with acuminate to short-aristate (vs. aristate) apices with each acumen or arista $1 / 5-1 / 4$ (vs. arista $1 / 8$ ) the length of the leaf lamina, and lateral leaves with truncate, rounded or slightly acute (vs. acute) apices. In addition, $S$. mendoncae is so far known only from the states of Rio de Janeiro and Sao Paulo in Brazil (Alston et al. 1981; Hirai \& Prado 2000) leaves.

3. Selaginella convoluta (Arn.) Spring, Fl. Bras. 1(2): 131. 1840. Lycopodium convolutum Arn., Mem. Wern. Nat. Hist. Soc. 5: 199. 1824. Type: Brazil, Rio de Janeiro, W. Jameson s.n. (holotype: E not seen).

\section{Fig. 1H-J}

Stem erect or ascending, greenish to brownish, often forming a rosette and ocassionally enrolling inward when dry, to $29 \mathrm{~cm}$ long, 0.8-1.3 mm diam., vascular bundle one; terminal branch 2.1-4.9 mm wide. Rhizophores ventral, present on base of stem. Leaves anisophyllous, sometimes isophyllous at base. Lateral leaves $1.4-4.1 \times 0.7-2.2 \mathrm{~mm}$, adpressed at base, slightly ascending at apex, peltate, ovate, ovate-elliptic or ovate-lanceolate, base rounded acroscopically, margins serrate to erose-lacerate, apex acute to cuspidate, upper surface rugose. Axillary leaves similar to the lateral leaves, but 1.4-3.9 x 0.7-1.9 mm, apex acute, acuminate or cuspidate, upper surface smooth. Dorsal leaves $0.8-3.2 \times 0.5-1.4 \mathrm{~mm}$, peltate, ovate-lanceolate to lanceolate, base rounded to slightly auriculate externally, rounded internally, margins serrate to short-ciliate, apex acute to acuminate, rarely attenuate, upper surface smooth. Strobilus to $28.8 \mathrm{~mm}$ long, dorsal sporophylls shorter than ventral sporophylls, rarely equal in length. Dorsal sporophylls carinate, carina generally serrate at least near apex, ovate-lanceolate, margins erose-lacerate 
to serrate. Ventral sporophylls carinate, ovate-lanceolate to deltoid, margins erose-lacerate to serrate. Megaspores cream. Microsporophylls orangish.

Distribution and habitat: Widely distributed in Brazil (Piauí, Ceará, Paraíba, Pernambuco, Bahia, Goiás, Minas Gerais, Espírito Santo, Rio de Janeiro, and São Paulo) where it grows in open areas, generally on granite, gneiss and limestone rocks.

Selected specimens examnied: BRAZIL. Minas Gerais: Aimorés, margens do rio Manhuaçu, 24/V/2009, T.E. Almeida et al. 1944 (BHCB); Alto Caparaó, Parque Nacional

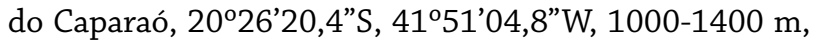
24/XI/2006, A. Salino et al. 11483 (BHCB); Januária, Vale do rio Peruaçu, 21/VII/1997, A. Salino et al. 3332 (BHCB); Pocrane, Serra do Azeite, 1/V/2009, T.E. Almeida et al. 2015 (BHCB).

Comments: Selaginella convoluta is characterized by its branches in rosettes, enrolled when dry, and peltate leaves. In Minas Gerais there are no records of species that are similar to $S$. convoluta, especially because it has branches in rosettes.

4. Selaginella decomposita Spring, Fl. Bras. 1(2): 123. 1840. Syntypes: Brazil, Rio de Janeiro, Sebastianópolis, G.H. Langsdorffs.n. (B not seen, K! [K000589167]), [Serra dos Orgaos, May 1839], J.B.A. Guillemin 962 (BM), P! [P00044838], P! [P00044839], possible isosyntype G!).

Selaginella subsebregata Baker, J. Bot. 21: 334. 1883. Type: Brazil, Rio de Janeiro, Glaziou 4501 (holotype: K!; isotype: B! [B200095563]).

Selaginella assurgens Baker, J. Bot. 22: 277. 1884. Syntypes: Brazil, Gardner 76 (K! [K000589119]), Burchell 2238 (K! [K000589120]), Glaziou 5215 (B! [B200094937], K! [K000589121], P-image! [P00559334], P! [P00044840], P [P00044841]), Glaziou 5637 (B! [B200094938], K-image! [K000639233]), P-image! [P00559333], Glaziou 7968 (B! [B200094939], K! [K000589118], P! [ P00044842], P! [P00044843])

Selaginella fusca Silveira, Bol. Commiss. Geogr. Geol. Minas Geraes 5: 123. 1898. Type: Brazil, Minas Gerais, Serra Negra, entre Lima Duarte e Rio Preto, VII/1898, G.H. Magalhães s.n.; n. 2918 in herb. Com. Geog. et Geol. Civitatis Minas Geraes (possible holotype: R! [as Hebarium Silveira n. 162, R 179575]; isotype: B! [B200095194]).

\section{Fig. 1K-N}

Stem erect, greenish to stramineous, to $35 \mathrm{~cm}$ long, 0.5-2.2 mm diam., vascular bundle one; terminal branch 2.1-4.2 mm wide. Rhizophores ventral, rarely dorsal and ventral on same bifurcation, present on lower $1 / 2$ of stem. Leaves anisophyllous, lateral leaves at base of stem distant, separated by $1.2-2.8 \mathrm{~mm}$, rarely closer but never imbricating. Lateral leaves $1.5-4.7 \times 0.6-2.1 \mathrm{~mm}$, ascending, rarely patent, basifixed, ovate-lanceolate, rarely oblong-lanceolate, base slightly rounded acroscopically, margins serrate to entire, apex acute to acuminate, upper surface smooth. Axillary leaves similar to the lateral leaves, but 1.5-3.9 $\times 0.6-1.8 \mathrm{~mm}$, base truncate to slightly rounded. Dorsal leaves $1.2-3.5$ x 0.5-1.7 mm, basifixed, elliptic, rarely ovate-lanceolate, base slightly rounded, margins serrate, slightly hyaline, with elongate, translucent cells, apex long-aristate, arista more than $1 / 3$ of the length of the leaf. Strobilus to $15.6 \mathrm{~mm}$ long, dorsal sporophylls equal or shorter than ventral sporophylls. Dorsal sporophylls carinate, carina generally serrate, at least near apex, lanceolate, rarely ovate-lanceolate, with margins serrate, hyaline to slightly hyaline, with elongate, translucent cells. Ventral sporophylls carinate, lanceolate, rarely ovate-lanceolate, margins serrate, hyaline to slightly hyaline, with elongate cells. Megaspores yellow to cream. Microspores orangish or pale orange.

Distribution and habitat: Restricted to Brazil (Ceará, Bahia, Minas Gerais, Espírito Santo, Rio de Janeiro, São Paulo, Paraná, Santa Catarina and Rio Grande do Sul) where it is frequently found growing in forest understory. Selected specimens examined: BRAZIL. Minas Gerais: Lambari, Parque Estadual de Nova Baden, 13/VII/2007, A. Salino, et al. 12534 (BHCB); Rio Preto, Serra Negra, 29/ IV/2008, A. Salino et al. 13275 (BHCB); Santa Maria do Salto, Distrito de Talismã, A. Salino et al. 10069 (BHCB); Simonésia, RPPN Mata do Sossego, 21/V/2006, A. Salino et al. 11139 (BHCB).

Comments: Selaginella decomposita is characterized by its erect habit, lateral leaves that are usually ascending and ovate-lanceolate (rarely oblong-lanceolate), and dorsal leaves with a long-aristate apex. Selaginella erectifolia is the most similar species and can be differentiated by its lateral leaves that are approximate to contiguous (less than $1.0 \mathrm{~mm}$ apart from each other), and dorsal leaves with an acuminate to short-aristate apex. Another character that can be used to distinguish these two species is the apex of the dorsal leaves and dorsal sporophylls, which is entire on the upper surface (vs. serrate in S. decomposita).

5. Selaginella erectifolia Spring, Mem. Acad. r. Sci. Lett. Belg. 24: 12. 1849. Type: Brazil, Rio de Janeiro, W. Swainson s.n.[36] (holotype: K! [K001044506]).

Selaginella camptostachys Fée, Crypt. vasc. Brésil p. 229. 1869. Type: Brazil, Rio de Janeiro, A.F.M. Glaziou 2242 (holotype: P-image! [P00559319]; isotypes: B! [B200095173], BR!, K! [K001044508], C!).

\section{Fig. 10-R}

Stem erect, greenish to stramineous, to $11 \mathrm{~cm}$ long, 0.4$0.7 \mathrm{~mm}$ diam., vascular bundle one; terminal branch 1.2$2.6 \mathrm{~mm}$ wide. Rhizophores ventral, present on lower $1 / 3$ of stem, rarely on lower $1 / 2$. Leaves anisophyllous, the lateral leaves at the base of the stem approximate to contiguous, less than $0.9 \mathrm{~mm}$ apart. Lateral leaves 1.1-2.1 x 0.5-1.0 $\mathrm{mm}$, ascending, slightly incurved at the apex, basifixed, ovate-lanceolate to oblong-lanceolate, base slightly rounded on acroscopic side, margin acroscopically serrate 

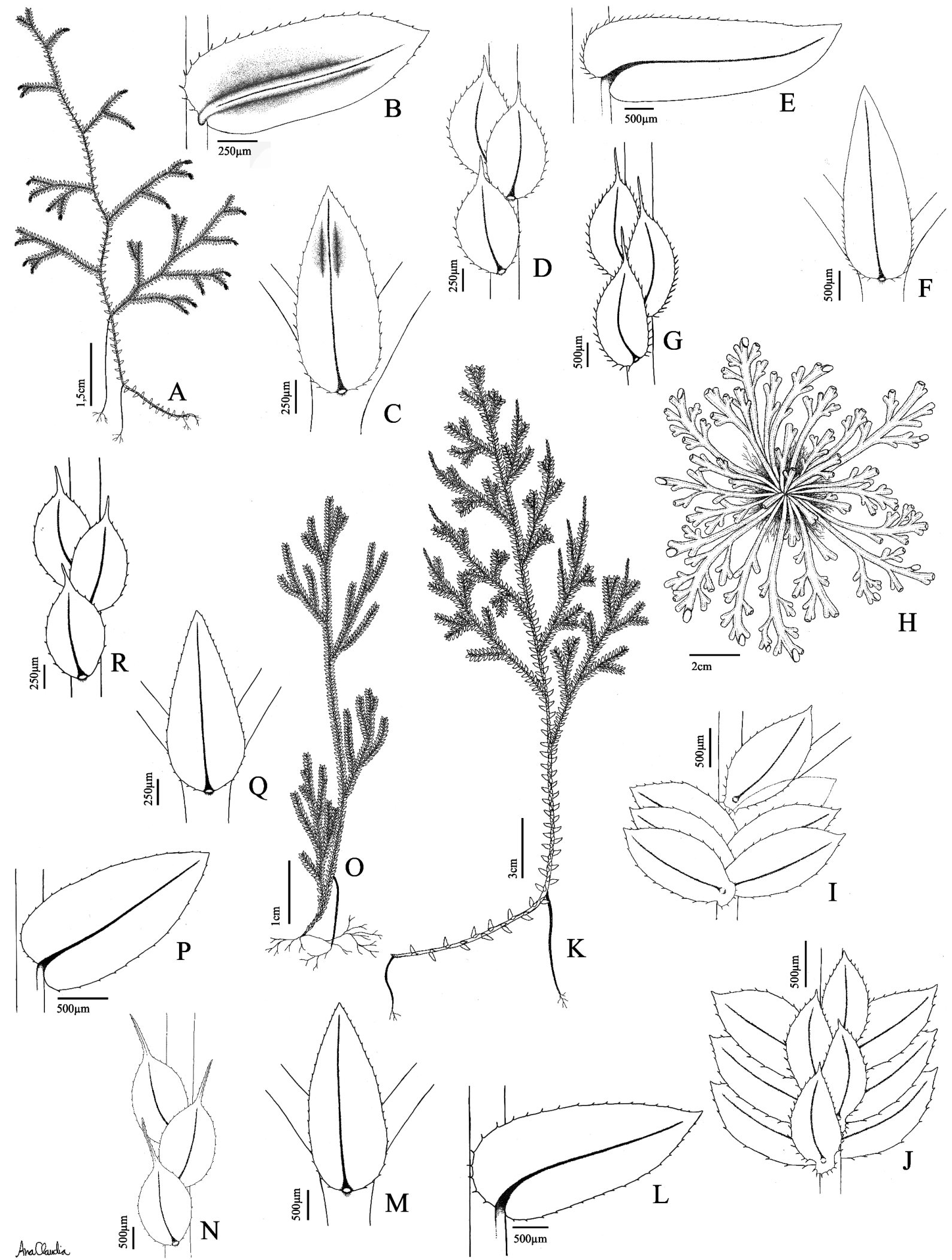

Figure 1. A-D. Selaginella alstonii G. Heringer, Salino \& Valdespino (Almeida 533). A. Habit. B. Ventral view of lateral leaf; C. Ventral view of axillary leaf; D. Dorsal view of dorsal leaves. E-G. Selaginella contigua Baker (Condack 100). E. Ventral view of lateral leaf; F. Ventral view of axillary leaf; G. Dorsal view of dorsal leaves. H-J. Selaginella convoluta (Arn.) Spring (Salino 3332). H. Habit; I. Dorsal view of branch; J. Ventral view of branch at bifurcation. K-N. Selaginella decomposita Spring (Salino 11139). K. Habit; L. Ventral view of lateral leaf; M. ventral view of axillary leaf; N. Dorsal view of dorsal leaves. O-R. Selaginella erectifolia Spring (Badini 316). O. Habit; P. Ventral view of lateral leaf; Q. Ventral view of axillary leaf; R. Dorsal view of dorsal leaves. 
to entire, apex acute to cuspidate, upper surface smooth. Axillary leaves similar to the lateral leaves, but 1.0-2.0 x 0.6-1.2 mm, ovate to ovate-lanceolate, base truncate to slightly rounded. Dorsal leaves 1.2-1.7 x 0.6-0.9 mm, basifixed, ovate to elliptic, base slightly rounded, margins serrate, slightly hyaline, with elongate, translucent cells, apex acuminate, short-acuminate or short-aristate, not dorsally serrate, arista less than $1 / 3$ of leaf. Strobilus to $16.2 \mathrm{~mm}$ long, dorsal and ventral sporophylls equal in length. Dorsal sporophylls carinate, carina not serrate, ovate-lanceolate, rarely lanceolate, margins serrate. Ventral sporophylls carinate, ovate-lanceolate, rarely lanceolate, margins serrate. Megaspores white to yellow. Microspores orangish or pale orangish.

Distribution and habitat: Restricted to southeastern and southern Brazil (Minas Gerais, Rio de Janeiro and Santa Catarina).

Selected specimens examined: BRAZIL. Minas Gerais: Ouro Preto, Serra do Itacolomi, 1936, J. Badini 316 (RB); Idem, São Bartolomeu, 13/X/2007, V.A.O. Dittrich et al. 1499 (BHCB); Idem, 1904, C.A.W. Schwacke 1688 (BHCB); Santa Bárbara, RPPN Capinari, 12/XII/2009, A.J. Arruda et al. 23 (BHCB); s.m., Serra do Cipó, VI/1908, L.B. Damazio s.n. (RB 39076). Comments: Selaginella erectifolia is characterized by its erect habit, lateral leaves that are ascending, ovatelanceolate to oblong-lanceolate, and approximate to contiguous at the base of the stem, and dorsal leaves that are acuminate, short-acuminate or short-aristate with an entire apex (dorsally). Among the species that occur in the state, $S$. decomposita is the most similar and can be differentiated by the characteristics mentioned under the comments of that species.

6. Selaginella erythropus (Mart.) Spring, Fl. Bras. 1(2): 125. 1840. Lycopodium erythropus Mart., Icon. Select. Pl. Crypt. Bras. 39. 1834. Type: Brazil, Piauí, Martius s.n. (BR not seen).

\section{Fig. 2A-D}

Stem erect, reddish to greenish or stramineous, to $19 \mathrm{~cm}$ long, 0.6-1.4 mm diam., stoloniferous, reddish at the base, vascular bundle one; terminal branch 1.5-2.8 $\mathrm{mm}$ wide. Rhizophores obscurely ventral, present on lower $1 / 2$ of stem, reddish. Leaves isophyllous at base, anisophyllous above first bifurcation. Lateral leaves 1.1-2.8 x 0.5-1.6 $\mathrm{mm}$, adpressed at base, slightly ascending at apex, basifixed, ovate-lanceolate to lanceolate, slightly falcate, base slightly rounded acroscopically, margins ciliate to serrate, rarely entire, slightly hyaline, with elongate, translucent cells, apex acuminate to attenuate, upper surface smooth to rugose. Axillary leaves similar to the lateral leaves, but 1.2-2.7 x 0.4-1.4 mm, base rounded, sometimes slightly cordate on one side. Dorsal leaves 0.9-3.0 x 0.4-1.3 mm, basifixed, ovate-lanceolate, base rounded, margins ciliate, hyaline to slightly hyaline, with translucent, elongate cells, apex long-aristate to long-acuminate, serrate on margins and dorsally, arista more than $1 / 3$ of the leaf, upper surface smooth to rugose, idioblasts inconspicuous or absent. Strobilus to $14.4 \mathrm{~mm}$ long, dorsal and ventral sporophylls equal in length. Dorsal sporophylls carinate, carina serrate, lanceolate, margins short-ciliate to serrate, hyaline to slightly hyaline, with elongate cells. Ventral sporophylls carinate, ovate-lanceolate, margins short-ciliate to serrate, slightly hyaline, with elongate cells. Megaspores white to pale. Microspores orangish.

Distribution and habitat: Widely distributed in Brazil (Piauí, Ceará, Bahia, Mato Grosso, Mato Grosso do Sul, Distrito Federal, Minas Gerais and Rio de Janeiro) where it is associated with the Cerrado domain.

Selected specimens examined: BRAZIL. Minas Gerais: Bocaiúvas, estrada Canta Galo - Caçaratiba, 16/III/2007, A. Salino et al. 11829 (BHCB); São Gonçalo do Abaeté, 26/I/2001, R.C. Mota 417 (BHCB); Tiros, 24/III/2001, A. Salino 6387 (BHCB); Turmalina, Posses, 24/I/2004, J.R. Pirani et al. 5268 (SPF).

Comments: Selaginella erythropus is characterized by the presence of stolons, the reddish color at the base of the main stem and isophyllous leaves at the base of the stem that turn anisophyllous towards the first branch.

7. Selaginella flexuosa Spring, Flora, Jena 21: 197. 1838. Syntypes: Brazil, Rio de Janeiro, Corcovado, Raddi s.n. (PI not seen); Próximo ao Rio de Janeiro, G.H. Langsdorffs.n. (BR not seen, M!; probable syntype: P! [P00044869], P! [P00044870]); Desvaux (B!); Sellow (B!).

Selaginella bella Fée, Crypt. vasc. Brésil suppl. p. 100.1873. Syntypes: Brazil, Rio de Janeiro, Petrópolis, A.F.M. Glaziou 4491 (B-image! [B200094953], F!, K! [K000589102], P-2 sheets!, P-image! [P00044872]-[P00044871], US!); A.F.M. Glaziou 4494 (B-image! [B200094954], P-image! [P00559302]); Morro Queimado, A.F.M. Glaziou 4504 (GH!, P-image! [P00044873], US not seen).

Selaginella macrorhyza Silveira, Bol. Commiss. Geogr. Geol. Minas Geraes 5: 122. 1898. Type: Brazil, Minas Gerais, Rio Preto, VI/1898, G.H. Magalhães s.n., n. 2820 in herb. Com. Geog. et Geolog. Civitatis Minas Geraes (possible holotype: R! [as Herbarium Silveira n. 161, R179626]; isotype: B! [B200129649].

Selaginella longicuspis Baker, J. Bot. 21: 241. 1883. Type: Brazil, Rio de Janeiro, Tijuca, Apr 1875, A.F.M. Glaziou 9353 [holotype: K! [K000589103]; isotypes: BM!, G!]

\section{Fig. 2E-G}

Stems prostrate, ascending or erect, greenish to stramineous, to $36 \mathrm{~cm}$ long, $0.4-1.3 \mathrm{~mm}$ diam., vascular bundle one; terminal branch 2.0-6.5 mm wide. Rhizophores ventral, present throughout stem. Leaves anisophyllous. Lateral leaves $1.4-3.9 \times 0.6-2.1 \mathrm{~mm}$, patent to slightly ascending, basifixed, oblong to ovate-oblong, base slightly rounded acroscopically, margins serrate to entire, apex obtuse, upper surface rugose. Axillary leaves similar to the lateral leaves, but 1.2-2.8 x 0.7-1.6 mm, ovate, ovate-lanceolate or 
ovate-oblong, apex acute to cuneate. Dorsal leaves 1.1-2.4 $\mathrm{x} 0.5-1.3 \mathrm{~mm}$, basifixed, elliptic to ovate-elliptic, base slightly rounded, margins ciliate to serrate towards the apex, not hyaline to slightly hyaline, with elongate, translucent cells, apex aristate to long-aristate, ca. $1 / 3$ the length of the leaf, arista serrate, upper surface rugose. Strobilus to $12.5 \mathrm{~mm}$ long, quadrangular, with 4 rows of sporophylls, dorsal sporophylls equal or shorter in length than ventral sporophylls.

Dorsal sporophylls carinate, carina generally serrate, at least near apex, ovate-lanceolate, margins serrate. Ventral sporophylls carinate, ovate to ovate-lanceolate, margins serrate. Megaspores white. Microspores orangish or yellow. Distribution and habitat: Widely distributed in Brazil (Pernambuco, Bahia, Mato Grosso, Distrito Federal, Minas Gerais, Espírito Santo, Rio de Janeiro, Paraná and Santa Catarina), occurring in various habitats.

Selected specimens examined: BRAZIL. Minas Gerais: Boa Esperança, Parque Estadual da Serra da Boa Esperança, 14/XII/2007, A. Salino et al. 13005 (BHCB); Grão Mogol, 15/III/2007, A. Salino et al. 11806 (BHCB); Santa Rita do Itueto, Parque Estadual de Sete Salões, 9/V/2006, A. Salino et al. 10989 (BHCB); Turmalina, Estação Ecológica de Acauã, 3/VII/2006, A. Salino et al. 11244 (BHCB).

Comments: Selaginella flexuosa is characterized by leaves with a rugose surface and serrate margins, and oblong to ovate-oblong, lateral leaves. Selaginella macrostachya also has leaves with a rugose surface but differs by having ciliate leaves and lateral leaves that are usually reflexed. Selaginella contigua is another species that can be confused with $S$. flexuosa because of its habit and leaf surface, which is frequently rugose, but differs by the presence of conspicuously ciliate leaves, at least basally, and oblong to long-oblong, lateral leaves.

8. Selaginella jungermannioides (Gaudich.) Spring, Bull. Acad. r. Belg. 10: 143. 1843. Lycopodium jungermannioides Gaudich. Voyage Autour Monde Bot (Voy. Uranie). 286 [826]. 1828. Syntypes: Brazil, Rio de Janeiro, [1819] C. Gaudichaud s.n. [16] (P [P04026280], Rio de Janeiro, C. Gaudichaud s.n. (K not seen, fide Alston et al. 1981).

\section{Fig. 2H-K}

Stem prostrate, greenish to stramineous, to $42 \mathrm{~cm}$ long, 0.4-0.8 mm diam., vascular bundle one; terminal branch 2.3-6.8 mm wide. Rhizophores ventral, rarely axillary or ventral and dorsal on the same bifurcation, present throughout stem. Leaves anisophyllous. Lateral leaves similar to the lateral leaves, but 1.5-3.5 x 0.7-2.0 mm, patent, rarely incurved exposing lower surface, basifixed, ovate to ovateoblong, base cordate and passing under stem acroscopically, margins long-ciliate, apex acute to obtuse, upper surface smooth. Axillary leaves similar to the lateral leaves, but 1.2-2.6 $\times$ 0.6-1.4 mm, ovate to ovate-lanceolate, base truncate. Dorsal leaves 1.0-2.4 x 0.6-1.4 mm, basifixed, ovate to ovate-lanceolate, base slightly rounded to rounded, margins ciliate, hyaline to slightly hyaline, with elongate, translucent cells, apex acuminate to long-acuminate, margins ciliate to serrate towards the apex. Strobilus to $25.9 \mathrm{~mm}$ long, dorsal sporophylls shorter than ventral sporophylls, rarely equal in length. Dorsal sporophylls carinate, carina serrate, at least near apex, ovate-lanceolate, margins serrate. Ventral sporophylls carinate, ovate-lanceolate, margins serrate. Megaspores white to cream. Microspores orangish.

Distribution and habitat: Restricted to southeastern Brazil (Minas Gerais, Espírito Santo and Rio de Janeiro). Terrestrial or rupicolous in campos rupestres and on rocky cliffs, ravines and riverbanks.

Specimens examined: BRAZIL. Minas Gerais: Carangola, Fazenda Santa Rita, 31/III/1987, L. Krieger et al. s.n. (CESJ 21471); Conceição do Mato Dentro, 24/IX/2005, T.E. Almeida et al. 122 (BHCB); Conselheiro Pena, Parque Estadual dos Sete Salões, 7/V/2006, A. Salino et al. 10912 (BHCB); Inhapim, 30/V/2009, T.E. Almeida et al. 1973 (BHCB); Santa Maria do Salto, Fazenda Duas Barras, 10/ III/2004, A. Salino et al. 9540 (BHCB).

Comments: Selaginella jungermannioides is cited here for the first time for the state of Minas Gerais. This species is characterized by its prostrate habit, ciliate lateral leaves and acuminate apex of its dorsal leaves. It was observed that some specimens of $S$. jungermannioides were determined as Selaginella contigua; however, $S$. contigua has an erect habit and dorsal leaves with aristate apices.

9. Selaginella macrostachya (Spring) Spring, Bull. Acad. Roy. Sci. Brux. 10:144. 1843. Selaginella flexuosa Spring subsp. macrostachya Spring, Fl. Bras. 1(2): 123. 1840. Syntypes: Brazil, without exact locality, F. Sellow s.n. (B-image! [B200129653 (a), (b), (c)]; isotype: K-image! [K000589072]).

Selaginella gardneri Spring, Mem. Acad. r. Sci. Lett. Belg. 24: 134. 1849. Type: Brazil, Orgãos Montes, Gardner s.n. (holotype: K, not seen).

Selaginella ericoides Fée, Crypt. vasc. Brésil p. 228, 1869. Syntypes: Brazil, Rio de Janeiro, A.F.M. Glaziou 2243 (Bimage! [B200129434], pro parte BR-image! [BR696471 (a)], P-image! [P00573783], P-image! [P00573784]; isotype: P-image! [P00573785]).

Selaginella geminata Fée, Crypt. vasc. Brésil suppl. p. 100. 1873. Syntypes: Brazil, Rio de Janeiro, Serra dos Órgãos, A.F.M. Glaziou 4484 (F-image! [F0075573], Pimage! [P00573786], P-image! [P00573787], P-image! [P00573788]).

Selaginella lindbergii Baker, J. Bot. 21: 99. 1883. Syntypes: Brazil, Minas Gerais, Lindberg s.n. (B-image! [B200129565], B-image! [B200129566], K-image! [K000589073]) São Paulo, Serra de Cubatao, Burchell s.n. (not located).

Selaginella henriqueana Silveira, Bol. Commiss. Geogr. Geol. Minas Geraes 5: 123.1898. Type: Brazil, Minas Gerais, Serra do Chora (Mantiquera), entre Serra de Ibitipoca e Rio Preto, V/1898, G.H. Magalhães s.n., n. 2759 in herb. Com. Geog. et Geolog. Civitatis Minas Geraes (possible holotype: R! [as Hebarium Silveira n. 163; R179588]; isotype: B! [B200129435]). 


\section{Fig. 2L-N}

Stem ascending or erect, greenish to stramineous, to 38 $\mathrm{cm}$ long, 0.7-1.1 mm diam., vascular bundle one; terminal branch 2.6-5.1 mm wide. Rhizophores ventral, rarely axillary or ventral and dorsal on the same bifurcation, present throughout stem or rarely on the lower $1 / 2$ of stem. Leaves anisophyllous. Lateral leaves 1.5-3.6 x 0.6-2.1 $\mathrm{mm}$, slightly reflexed to patent, rarely slightly ascending at apex, sometimes margins recurved acroscopically, basifixed, ovate to ovate-oblong, base cordate, generally passing below stem acroscopically, margins long- to short-ciliate, apex obtuse to cuspidate, upper surface rugose. Axillary leaves similar to the lateral leaves, but 1.1-2.9 x 0.6-2.1 $\mathrm{mm}$, apex acute, upper surface rugose. Dorsal leaves 0.9$2.6 \times 0.5-1.5 \mathrm{~mm}$, basifixed, ovate to elliptic, rarely deltoid, base slightly rounded, margins ciliate, slightly hyaline, with elongate, translucent cells, apex long-aristate, serrate on margins and dorsally, arista more than $1 / 3$ the length of the leaf, upper surface rugose. Strobilus to $12.5 \mathrm{~mm}$ long, dorsal sporophylls equal or shorter than ventral sporophylls. Dorsal sporophylls carinate, carina generally serrate at least near apex, ovate to ovate-lanceolate, with short-ciliate to serrate margins (except when undifferentiated). Ventral sporophylls carinate, ovate to ovate-lanceolate, with short-ciliate to serrate margins, cells not elongate (except when undifferentiated). Megaspores cream. Microspores orangish, reddish brown or cream.

Distribution and habitat: Restricted to Brazil (Bahia, Minas Gerais, Rio de Janeiro, São Paulo, Paraná and Santa Catarina).

Selected material: BRAZIL. Minas Gerais: Lima Duarte, Parque Estadual do Ibitipoca, 22/VI/2007, T.E. Almeida 1215 (BHCB); Rio Preto, Serra do Funil, 9/IV/2007, T.E. Almeida et al. 766 (BHCB); Santa Bárbara do Monte Verde, 24/IV/2004, J.P.S. Condack 140 (RB); Santa Rita de Jacutinga, 3/III/1987, L. Krieger s.n. pro parte (CESJ).

Comments: Selaginella macrostachya is recognized by the ciliate margins of the dorsal, axillary and lateral (acroscopically) leaves, by the rugose surface of the leaves and lateral leaves that are generally slightly reflexed. In the flora area, $S$. flexuosa and $S$. contigua are the most similar species to $S$. macrostachya but they can be separated by the characters discussed under the formers' descriptions.

10. Selaginella marginata (Humb. \& Bonpl. ex Willd.) Spring, Flora, Jena 21: 194. 1838.

Lycopodium marginatum Humb. \& Bonpl. ex Willd., Sp. pl. 5: 41. 1810. Type: Venezuela, Apure, R Meta, F.W.H.A. Humboldt \& A.J.A. Bonpland s.n., Ex. herbário Willd. (holotype: B not seen).

Selaginella excurrens Spring, Fl. Bras. 1(2): 128. 1840. Syntype Brazil, Minas Gerais, F. Sellow s.n., Ackermann s.n. (B not seen).

Selaginella chromatophylla Silveira var. chromatophylla, Bol. Commiss. Geogr. Geol. Minas Geraes 5: 124. 1898. Types: Brazil, Minas Gerais, Serra do Papagaio, XI/1897, A.A.
Silveira s.n., n. 2604 in herb. Com. Geog. et Geolog. Civitatis Minas Geraes (possible holotype: R! [as Hebarium Silveira n. 152; R179574]; isotypes: B-image! [B200129405 (b)], BM [as Hebarium Silveira n. 152] not seen).

Selaginella chromatophylla Silveira var. megasperma, Bol. Commiss. Geogr. Geol. Minas Geraes 5: 124. 1898. Types: Brazil, Minas Gerais, oeste de minas, entre cidade de Tiradentes e Casa de Pedra, VI/1898, A.A. Silveira s.n., n. 2756 in herb. Com. Geog. et Geolog. Civitatis Minas Geraes (possible holotype: R! [as Hebarium Silveira n. 160; R179581]; isotypes: B-image! [B200129406]), BM [as Hebarium Silveira n. 160] not seen).

Selaginella breuensis Silveira, Fl. Serras Mineiras 79. 1908. Type: Brazil, Minas Gerais, Serra do Cipó, Morro do Bréu, IV/1905, 1700 m, A.A. Silveira 395 in herb. Silveira (holotype: R! [R179580]; isotypes: B! [B200129435], P-image! [P00573791]).

\section{Fig. 20-R}

Stem prostrate, greenish to stramineous, to $46 \mathrm{~cm}$ long, 0.4-1.4 mm diam., vascular bundle one; terminal branch 1.8-5.3 mm wide. Rhizophores dorsal, present throughout stem, rarely reddish. Leaves anisophyllous. Lateral leaves $1.6-3.4 \times 0.6-1.7 \mathrm{~mm}$, patent to slightly reflexed, frequently recurved, peltate, ovate, elliptic or oblong, base auriculate, margins serrate, rarely short-ciliate, hyaline to slightly hyaline, with elongate, translucent cells, apex acute to acuminate, upper surface smooth. Axillary leaves similar to the lateral leaves, but $1.2-2.9 \times 0.5-1.3 \mathrm{~mm}$, apex acute. Dorsal leaves 1.2-3.0 x 0.5-1.4 mm, peltate, lanceolate-elliptic to elliptic, base auriculate on external side, sometimes biauriculate with larger outer auricle, margins serrate to short-ciliate, hyaline, with elongate, translucent cells, apex acute to acuminate, upper surface smooth. Strobilus to $6.9 \mathrm{~mm}$ long, with one basal megasporophyll followed by two microsporophylls, dorsal and ventral microsporophylls equal in length; megasporangia and megasporophylls ca. two times longer and wider than microsporangia and microsporophylls. Dorsal sporophylls carinate, lanceolate, margins serrate, hyaline, with elongate cells. Ventral sporophylls carinate, lanceolate, margins serrate, obscurely hyaline, with elongate cells. Megaspores whitish. Microspores cream or pale orange. Distribution and habitat: Widely distributed in Brazil (Maranhão, Piauí, Bahia, Mato Grosso, Mato Grosso do Sul, Goiás, Distrito Federal, Minas Gerais, Rio de Janeiro, São Paulo, Paraná, Santa Catarina and Rio Grande do Sul) where it grows in the interior of forests and in open areas on rocky outcrops.

Selected specimens examined: BRAZIL. Minas Gerais: Camanducaia, 19/VIII/2001, L.C.N. Melo et al. 129 (BHCB); Itabira, 2/VIII/2006, T.E. Almeida et al. 306 (BHCB); Januária, 23/V/1997, A. Salino 3027 (BHCB); Ouro Preto, Parque Estadual do Itacolomi, 5/I/2006, L.B. Rolim et al. 150 (BHCB). 
Comments: Selaginella marginata is easily identified by its articulate stem with only one vascular bundle, and peltate leaves. Somers (1978) threated S. marginata in the broad sense since he found that microspores among specimens from different regions are highly variable. The preliminary studies of one of us (IAV) confirms not only microspore variations but that these are also present in megaspores sculpturing pattern and leaf morphology in specimens that match the type collection and some found in Brazil. These findings seem to indicate that, as currently defined, S. marginata is a species complex that may encompass various taxa and, thus, further studies are needed to solve it. 11. Selaginella microphylla (Kunth) Spring, Bull. Acad. Roy. Sci. Brux. 10: 234. 1843. Lycopodium microphyllum Kunth, Nov. gen. sp. 1: 39. 1816. Type: Colombia, Cauca, Quilquase, F.W.H.A. Humboldt \& A.J.A. Bonpland s.n. (holotype: B-image! [B200120790-3, B200120790-4]; isotype: P not seen, BM-image! [BM000066666]).

Selaginella thujaefolia Spring, Fl. Bras. 1(2): 120. 1840. Type: Uruguay, Montevidéu, F. Sellow s.n. (holotype: B not seen).

\section{Fig. 2S-T}

Stem prostrate, greenish to stramineous, to $17 \mathrm{~cm}$ long, 0.3-0.5 mm diam., vascular bundle one; terminal branch $0.5-1.8 \mathrm{~mm}$ wide. Rhizophores ventral, present throughout stem. Leaves anisophyllous. Lateral leaves $0.7-1.5$ $\mathrm{x}$ 0.4-0.9 $\mathrm{mm}$, ascending to adpressed, obliquely inserted, generally recurved and adpressed to the stem, basifixed, ovate, base rounded on acroscopic side, margins long- to short-ciliate acroscopically, apex obtuse to cuspidate, upper surface smooth to obscurely faveolate. Axillary leaves similar to the lateral leaves, but 0.6-1.1 x 0.4-0.6 mm, ovate-lanceolate to oblong, base truncate to rounded, apex acute. Dorsal leaves $0.7-1.3 \times 0.4-0.9 \mathrm{~mm}$, basifixed, ovate to widely elliptic, base rounded, margins ciliate, sometimes serrate, apex cuspidate to short-acuminate, generally with 1-3 cilia at the apex, upper surface smooth to obscurely faveolate. Strobilus to $8.5 \mathrm{~mm}$ long, dorsal and ventral sporophylls equal in length. Dorsal sporophylls carinate, carina serrate, at least near apex, ovate-lanceolate, margins ciliate to serrate at apex. Ventral sporophylls carinate, ovate-lanceolate, margins ciliate to serrate at apex. Megaspore cream. Microspore orangish or reddish.

Distribution and habitat: Southeastern and southern Brazil (Minas Gerais Rio de Janeiro, São Paulo, Paraná, Santa Catarina and Rio Grande do Sul), frequently rupicolous near rivers.

Specimens examined: BRAZIL. Minas Gerais: Aiuruoca, RPPN do Matutu, 11/X/2004, A. Salino et al. 9761 (BHCB); Ouro Preto, Serra de Ouro Preto, 12/II/1893, C.A.W. Schwacke 9169 (RB); Sapucaí Mirim, 30/VII/1988, A. Salino 517 (BHCB, UEC).

Comments: Selaginella microphylla can be differentiated by its prostrate habit, ciliate leaves and lateral leaves generally adpressed to the stem. Some specimens of S. microphylla, with adpressed lateral leaves, were misidentified as $S$. sellowii. However, the leaves of $S$. sellowii are isophyllous, acicular, and spiraly arraged throughout the stem.

12. Selaginella muscosa Spring, Fl. Bras. 1(2): 120. 1840. Type: Brazil, Rio de Janeiro, Sebastianópolis, B. Luschnath s.n. (holotype: probably B not seen; isotypes: B not seen, fide Alston et al. 1981, M not seen).

Lycopodium crassinervium Desv., Ann. Soc. Linn. Paris 6: 190. 1827. Selaginella crassinervia (Desv.) Spring, Fl. Bras. 1(2): 119. 1840. Type: Brazil, s.c. (holotype: P not seen). Selaginella apus Spring var. tetragonostachya Spring, Fl. Bras. 1(2): 119. 1840. Syntypes: Brazil, Rio de Janeiro, Sebastianópolis, J.E. Pohl s.n. (BR!, OXF!, W!).

Selaginella brevipes Fée, Crypt. vasc. Brésil p. 226. 1869. Type: Brazil, Rio de Janeiro, Serra dos Órgãos, A.F.M. Glaziou 2241 (holotype: P!; isotypes: B!, BR!, P!).

\section{Fig. 3A-C}

Stems prostrate, greenish to stramineous, ascending to erect, to $17 \mathrm{~cm}$ long, 0.4-0.8 $\mathrm{mm}$ diam., vascular bundle one; terminal branch $2.8-4.5 \mathrm{~mm}$ wide. Rhizophores ventral, rarely ventral and dorsal on the same bifurcation, present throughout stem. Leaves anisophyllous. Lateral leaves $2.0-3.5 \times 0.9-2.1 \mathrm{~mm}$, patent to slightly ascending, basifixed, ovate to ovate-lanceolate, base cordate, passing under the stem acroscopically, margins serrate, apex acute, upper surface smooth to slightly papillose, idioblasts numerous, rarely absent. Axillary leaves similar to the lateral leaves, but 1.7-2.9 $\times 0.8-1.5 \mathrm{~mm}$, margins serrate, not hyaline to slightly hyaline, with elongate, translucent cells, apex acute to cuspidate. Dorsal leaves 1.5-2.7 x 0.6$1.4 \mathrm{~mm}$, basifixed, ovate to ovate-elliptic, rarely cordiform, base rounded to cordate, margins serrate, not hyaline to slightly hyaline, with elongate, translucent cells, apex aristate to long-aristate, more than $1 / 3$ of leaf, serrate on margins and dorsally, upper surface smooth to slightly papillose, idioblasts numerous, rarely absent. Strobilus to 9.2 (35.3) $\mathrm{mm}$ long, dorsal sporophylls longer than ventral sporophylls. Dorsal sporophylls carinate, carina serrate at the apex, lanceolate to long lanceolate, margins serrate, hyaline, with elongate cells, idioblasts numerous on upper surface, rarely absent. Ventral sporophylls carinate, lanceolate to long lanceolate, margins serrate, hyaline, with elongate cells. Megaspores cream. Microspores orangish.

Distribution and habitat: Widely distributed in Brazil (Amazonas, Bahia, Minas Gerais, Espírito Santo, Rio de Janeiro, São Paulo, Paraná, Santa Catarina and Rio Grande do Sul), occurring in various environments.

Specimens examined: BRAZIL. Minas Gerais: Buenópolis, Parque Nacional das Sempre Vivas, 28/IV/2007, T.E. Almeida et al. 821 (BHCB); Poté, 20/VIII/2004, J.A. Lombardi et al. 6050 (BHCB); Simonésia, RPPN Mata do Sossego, 20/V/2006, A. Salino et al. 11091 (BHCB), Simonésia RPPN Mata do Sossego, 2004'18.7' S, 42 04'13.1'W, 1150-1600 

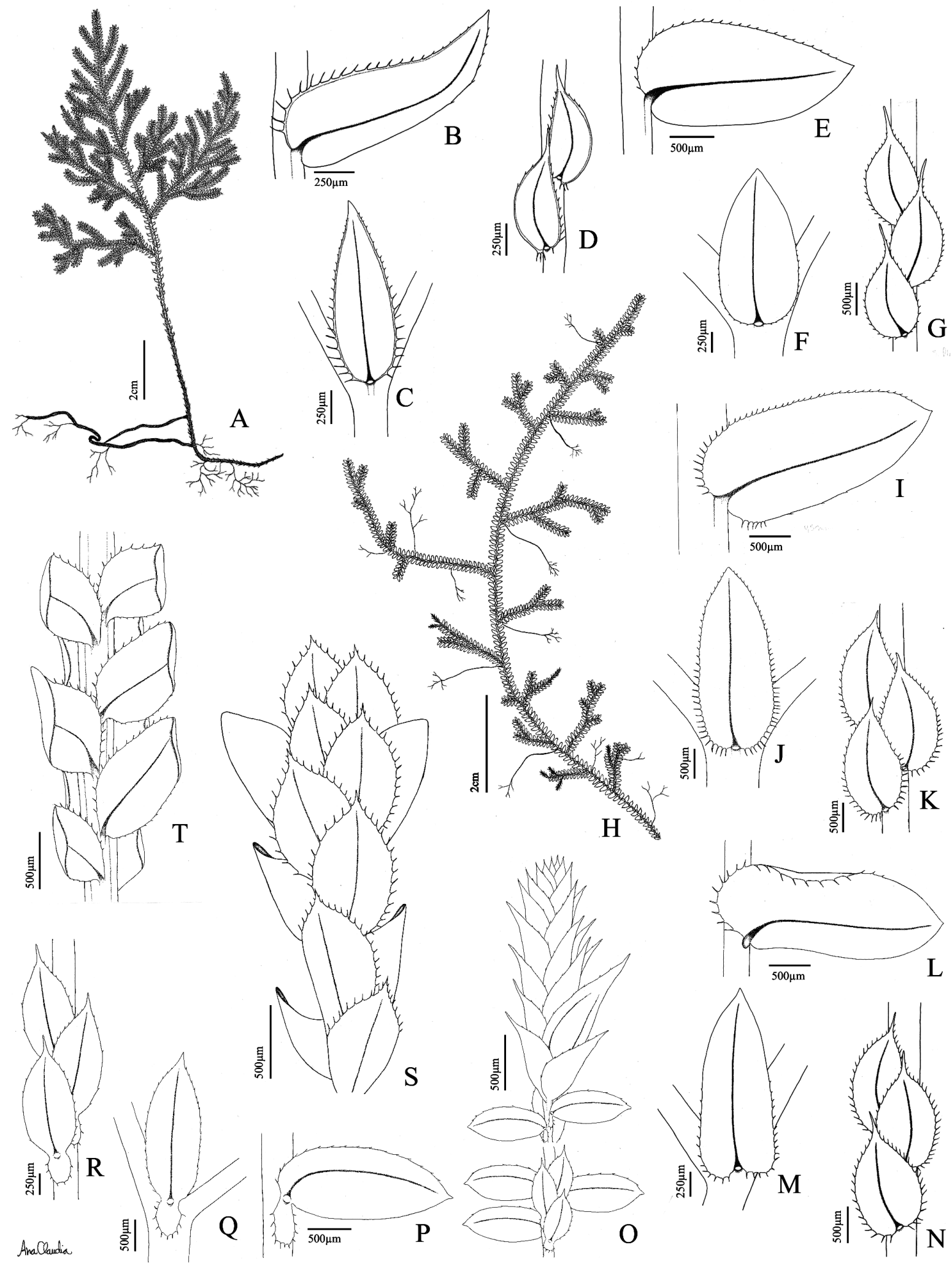

Figure 2. A-D. Selaginella erythropus (Mart.) Spring (Mota 417). A. Habit; B. Ventral view of lateral leaf; C. ventral view of axillary leaf; D. Dorsal view of dorsal leaves. E-G. Selaginella flexuosa Spring (Salino 10989). E. Ventral view of lateral leaf; F. ventral view of axillary leaf; G. Dorsal view of dorsal leaves. H-K. Selaginella jungermannioides (Gaudich.) Spring (Almeida 1973). H. Habit; I. Ventral view of lateral leaf; J. Ventral view of axillary leaf; K. Dorsal view of dorsal leaves. L-N. Selaginella macrostachya (Spring) Spring (Condack 140). L. Ventral view of lateral leaves; M. Ventral view of axillary leaves; N. Dorsal view of dorsal leaves. O-R. Selaginella marginata (Humb. \& Bonpl. ex Willd.) Spring (Rolim 150). O. Dorsal and ventral view of branch and ventral view of strobilus showing base of megasporophyll and apex of branch; P. Ventral view of lateral leaves; Q. Ventral view of axillary leaf; R. Dorsal view of dorsal leaves. S-T. Selaginella microphylla (Kunth) Spring (Salino 9761). S. Ventral view of apex of branch; T. Ventral view of branch showing recurved, lateral leaves. 
m, 24 Nov 2006, Salino et al. 11197 (BHCB., PMA); Virginópolis, 18/VIII/2005, T.E. Almeida et al. 110 (BHCB).

Comments: Selaginella muscosa is characterized by its leaves with idioblasts on the upper surface, lateral leaves with a cordate base acroscopically and dorsal leaves with an aristate apex. Alston et al. (1981) pointed out that S. muscosa is a variable and possibly mixed species. Valdespino (1995) concluded that S. deltoides A. Braun and S. trifurcata Baker, which were subsumed under S. muscosa by Alston et al. (1981), were the same taxon but not closely related to or conspecific with the latter species. Valdespino (1995) did confirm, however, some incipient racial differentiation between specimens from the northern, middle, and southern part of the $S$. muscosa distribution range that merits further investigation. We observed also some variability among specimens found in Minas Gerais, which suggest this taxon might be a species complex. In Minas Gerais, $S$. muscosa could be confused with $S$. tenuissima but this latter species lacks conspicuous idioblasts on the upper surface of leaves, has lateral leaves with obtuse to rounded apices and, axillary leaves oblong to oblong-obovate.

13. Selaginella producta Baker, J. Bot., Lond. 21: 243. 1883. Syntypes: GUYANA: C.F. Appun [196 or 197 or 198,] (K-image! [K000589093]), Drake s.n. (K-image! [K000589092]). BRAZIL. Amazonas. Between Barcellos and San Gabriel, Spruce 2043 (BM-n.v., CGE-n.v., K-image! [K000589089]); [fall of Taruma R., near Barra do Rio Negro, [Rio Tarumá, Feb 1855], Spruce 4731 (BM-n.v., CGEn.v., K-image! [K000589088], US-n.v., W!); San Gabriel [de Cachoeira], Spruce 2195 (K-n.v.; isotypes: CGE-n.v., K, RB!, NY-fragment!). Minas Geraes [Gerais].

\section{Fig. 3D-F}

Stem prostrate to ascending, greenish to vinaceous or greenish, to $13 \mathrm{~cm}$ long, 0.4-0.7 $\mathrm{mm}$ diam., sometimes vinaceous, vascular bundle one; terminal branch 2.8-5.7 $\mathrm{mm}$ wide, sometimes vinaceous. Rhizophores ventral, throughout stem, sometimes vinaceous. Leaves anisophyllous. Lateral leaves $2.5-4.3 \times 1.1-2.33 \mathrm{~mm}$, patent, rarely slightly reflexed or slightly ascending, basifixed, oblong or ovate-oblong, base strongly rounded on acroscopic side, margins serrate to entire, apex acute to obtuse, upper surface smooth to undulate. Axillary leaves similar to the lateral leaves, but 1.6-2.7 x 0.7-1.4 mm. Dorsal leaves 1.4-2.2 x 0.7-1.3 mm, basifixed, elliptic, base rounded, rarely forming a small auricle externally, margins serrate, not hyaline to slightly hyaline, with elongate, translucent cells, apex aristate to long-acuminate, serrate on margins and dorsally, upper surface smooth to undulate, idioblasts conspicuous. Strobilus to $15.7 \mathrm{~mm}$ long, dorsal and ventral sporophylls equal in length. Dorsal sporophylls carinate, carina serrate, lanceolate, margins serrate, upper surface with idioblasts. Ventral sporophylls carinate, lanceolate, margins serrate. Megaspores cream. Microspores orangish or pale orange.
Distribution and habitat: Brazil (Amazonas, Bahia, Espírito Santo, Mato Grosso, Goiás, Minas Gerais, Paraná and Pernambuco), found in the interior of forests, often terrestrial in ravines.

Additional selected specimens examined: BRAZIL. Bahia: Una, 17/XII/1966, L. Emygdio et al. 2475 (R); Espírito Santo: Cariacica, Reserva Biológica de Duas Bocas, 12/ VI/2010, G. Heringer et al. 476 (BHCB); Santa Teresa, Reserva Biológica de Santa Lúcia, 24/II/2003, A. Salino et al. 8328a (BHCB); Mato Grosso: Vila Bela da Santissima, 14/I/1987, J. Prado et al. 14 (SPF).

Comments: Selaginella producta can be distinguished by usually having a vinaceous color, especially in the field, lateral leaves oblong to ovate-oblong and dorsal leaves with conspicuous idioblasts on the upper surface. Among the species that occur in Minas Gerais, S. flexuosa is differentiated by its leaves with a rugose surface, dorsal leaves without idioblasts and green color. The only known specimen (i.e., Lindberg s.n., K) of S. producta in Minas Gerais was cited by Baker (1883: 243), which he included as a syntype of that species. He, apparently, cited the same specimen (Baker 1883: 99) as a syntype of S. lindbergii Baker. Alston (1981: 303) excluded Lindberg s.n., from S. producta and referred $S$. lindbergii as a synonym of $S$. macrostachya. Our examination of a digital imagen of Lindberg s.n. (K-image! [K000589073] causes us to agree with Alston et al. (1981) in considering it $S$. macrostachya. Nevertheless, we have included S. producta in this treatment as a species to be expected in Minas Gerais given that it has been collected in adjacent states.

14. Selaginella sellowii Hieron., Hedwigia 39: 306. 1900. Lectotype (chosen by R. Tyron, 1955: 34): Brazil, Praia de São Diego, 1821, F. Sellow s.n. (1955: B-image! [B200129700]; isolectotypes: K-image! [K000589052], NY-image! [NY99573]-[NY99577]).

\section{Fig. 3G}

Stem prostrate, greenish to stramineous, to $7 \mathrm{~cm}$ long, 0.3-0.5 mm diam., vascular bundle one; terminal branch 0.6-1.3 mm wide. Rhizophores present throughout stem. Leaves isophyllous, spiral, $1.3-2.0 \times 0.2-0.4 \mathrm{~mm}$, adpressed to strongly ascending, frequently bicolorous with one brown, central bundle, basifixed, symmetric, acicular, with a central groove, base truncate, margins serrate to short-ciliate throughout, apex cuneate, with apical seta, surface smooth. Strobilus to $19.2 \mathrm{~mm}$ long. Sporophylls lanceolate, margins serrate to short-ciliate, apex with apical seta. Megaspores yellow. Microspores yellow.

Distribution and habitat: Widely distributed in Brazil (Bahia, Mato Grosso, Mato Grosso do Sul, Minas Gerais, Espírito Santo, Rio de Janeiro, São Paulo and Rio Grande do Sul) where it is rupicolous on rocky outcrops or terrestrial. Selected specimens examined: BRAZIL. Minas Gerais: Almenara, Fazenda Limoeiro, 29/II/2004, A. Salino et al. 9404 (BHCB); Carangola, Pedra do São Bento, 22/ 
XI/1995, A. Salino 2259 (BHCB); Itinga, RPPN Purpureus, 27/VI/2008, T.E. Almeida 1450 (BHCB); Pedra Azul, 19/X/1988, R.M. Harley et al. 25212 (SPF); Idem, 28/V/1999, A. Salino et al. 4728 (BHCB).

Comments: Selaginella sellowii is the only species in the state that is completely isophyllous. In addition to the isophyllous leaves, this species can be recognized by its acicular, spirally arranged leaves, each with a whitish apical seta that is sometimes caducous.

15. Selaginella sematophylla Valdespino, G. Heringer \& Salino Phytokeys. 50: 51. 2015.

\section{Fig. 3H-K}

Stem prostrate, stramineous, to $5 \mathrm{~cm}$ long, $0.1-0.3 \mathrm{~mm}$ diam., not articulate, not stoloniferous, pale to green, vascular bundle one; sterile terminal branch 1.6-2.4 $\mathrm{mm}$ wide, 1(2) pinnate, green. Rhizophores ventral to axillary, present throughout stem, pale. Leaves anisophyllous throughout stem. Lateral leaves 1.0-2.2 $\mathrm{x}$ 0.6-1.2 mm, patent, basifixed, ovate to ovate-oblong, base rounded on acroscopic side, margin long- to short-ciliate acroscopically and serrate to short-ciliate basiscopically, slightly hyaline to light green on upper surface, with elongate, translucent cells, apex acute, chloroplasts slightly evident, upper surface smooth to slightly papillose, with or without idioblasts. Axillary leaves similar to the lateral leaves, but chloroplasts not evident. Dorsal leaves 0.8-1.4 x 0.4-0.7 mm, basifixed, lanceolate, base slightly rounded to oblique, margins serrate to denticulate, conspicuously hyaline on upper surface, with elongate, translucent cells, apex acute, chloroplasts slightly evident, upper surface smooth to slightly papillose, with conspicuous idioblasts. Strobilus to 8.0 $\mathrm{mm}$ long, quadrangular, dorsal and ventral sporophylls equal in length. Dorsal sporophylls strongly ascending, carinate, carina serrate or not, ovate-lanceolate to lanceolate, with margins short-ciliate to serrate, hyaline, with elongate cells, apex acute, chlorophyll present, idioblasts present on upper surface (except when not differentiated). Ventral sporophylls ascending, carinate, ovate-lanceolate to lanceolate, with margin short-ciliate to serrate, obscurely hyaline, with elongate cells, apex acute, chlorophyll present (except when dimorphic). Megaspores white to yellow. Microspores orangish. Distribution and habitat: Restricted to southeastern Brazil (Minas Gerais, Espírito Santo and Rio de Janeiro) where it grows in campos rupestres in areas that are humid and in the shade.

Specimens examined: BRAZIL. Minas Gerais: Rio Pardo de Minas, Parque Estadual da Serra Nova, 13/III/2007, A. Salino et al. 11734 (BHCB); São Sebastião do Paraíso, 26/ IV/1949, A.C. Brade 3461 (CESJ).

Additional selected specimens examined: BRASIL. Espírito Santo: Santa Maria do Jetibá, 28/VIII/2009, A. Salino et al. 14543 (BHCB).
Comments: Selaginella sematophylla can be distinguished by its prostrate habit, lateral leaves oblong to ovate-oblong, dorsal leaves lanceolate with an acute apex, conspicuous hyaline margins and the presence of idioblasts on the adaxial surface. This species can be differentiated from $S$. vestiens because the latter has an erect habit, dorsal leaves with an acute to aristate apex and lacks idioblasts on the upper surface. In addition, S. sematophylla can be differentiated from $S$. jungermanioides since the latter has dorsal leaves that are ovate to ovate-lanceolate with an acuminate apex, and lacks idioblasts on the upper surface. Some specimens of $S$. sematophylla were identified as $S$. fragillima; however, after studying the type specimen of the latter species it was found that it is conspecific with S. vestiens (Valdespino et al. 2015).

16. Selaginella suavis (Spring) Spring, Bull. Acad. Roy. Sci. Brux. 10: 229. 1843. Selaginella sulcata (Desv. ex Poir.) Spring subsp. suavis Spring, Flora 21: 185. 1838. Type: Western do Brasil, without exact location, F. Sellow s.n. (holotype: B not seen; isotype: K-image! [K000589133]). Selaginella glaziovi Fée, Crypt. vasc. Brésil p. 232. 1869. Type: Brazil, Rio de Janeiro, A.F.M. Glaziou 2244 (holotype: P-image! [P00573814]).

\section{Fig. 3L-O}

Stem decumbent, stramineous, sometimes reddish near base, articulate (this sometimes difficult to see), to $37 \mathrm{~cm}$ long, 0.8-2.3 $\mathrm{mm}$ diam., vascular bundles two; terminal branch 4.1-8.3 mm wide. Rhizophores dorsal, present on lower $1 / 2$ of stem, rarely reddish. Leaves anisophyllous. Lateral leaves $2.1-4.9 \times 0.9-2.2 \mathrm{~mm}$, patent, rarely slightly ascending, basifixed, oblong to ovate-oblong, base shortly auriculate basiscopically, margins entire to serrate, hyaline to slightly hyaline, with elongate, translucent cells, apex cuspidate to acute, upper surface smooth, rarely with idioblasts. Axillary leaves similar to the lateral leaves, but 1.8-3.6 x 1.0-2.33 mm, ovate to ovate-lanceolate, base rounded, rarely truncate, apex acute. Dorsal leaves 1.3-3.2 x 0.5-1.7 $\mathrm{mm}$, basifixed, elliptic, rarely oblong, base auriculate, with external auricle, rarely biauriculate with larger external auricle, margins serrate, hyaline, with elongate cells, apex acuminate, rarely acute (sometimes appearing aristate), upper surface smooth, rarely with idioblasts. Strobilus to 10.1 (41.3) mm long, with one basal megasporophyll followed by two microsporophylls; megasporangia and megasporophylls ca. two times longer and wider than the microsporangia and microsporophylls. Dorsal sporophylls carinate, carina serrate at least near apex, lanceolate to ovate-lanceolate, margins serrate, hyaline, with elongate cells. Ventral sporophylls carinate, lanceolate to ovate-lanceolate, margins serrate, obscurely hyaline, with elongate cells. Megaspores white. Microspores cream.

Distribution and habitat: Brazil (Mato Grosso, Minas Gerais, Espírito Santo, Rio de Janeiro, São Paulo and Santa Catarina). Selected specimens examined: BRAZIL. Minas Gerais: 
Açucena, 26/III/2009, T.E. Almeida et al. 1906 (BHCB); Juiz de Fora, Morro do Imperador, VI/1902, C.A.W. Schwacke 14739 (RB); Passa Vinte, 14/II/2009, T.E. Almeida et al. 1801 (BHCB); São João Nepomuceno, 20/ VIII/1980, L. Krieger s.n. (CESJ 17354); s.m., Estação Benjemim Constant, 1933, P.P. Horta s.n. (RB 168982). Comments: Selaginella suavis can be easily identified by its articulate stem, two vascular bundles and lateral leaves with a basiscopic auricle. Of the species that occur in the state, $S$. sulcata can be distinguished by the presence of two auricles on the lateral leaves, the larger being acroscopic, and biauriculate axillary leaves (vs. not auriculate). An examination of digital images of Glaziou 2244 ([P00573915][BR0000006988616]) revealed that $S$. glaziovi Fée can be a synonym of $S$. sulcata. This observation was based on the presence of biauriculate, axillary and lateral leaves that could be seen in the images. However, as we have not seen the type material physically, we decided maintain $S$. glaziovi as a synonym of $S$. suavis and highlight that future studies should examine this material (Glaziou 2244) to resolve this issue.

17. Selaginella sulcata (Desv. ex Poir.) Spring ex Mart., Flora 2: 126. 1837. Lycopodium sulcatum Desv. ex Poir., Encycl. Suppl. 3: 549. 1814. Lectotype (chosen by Alston et al. 1981:321): Without exact location, ex herbarium Desvaux (P-image! [P573907]).

\section{Fig. 4A-C}

Stem decumbent, greenish to stramineous, to $44 \mathrm{~cm}$ long, 0.6-2.8 mm diam., articulate, vascular bundles two; terminal branch 2.7-8.9 mm wide, rarely reddish. Rhizophores dorsal, rarely dorsal and ventral on the same bifurcation, present on lower $1 / 2$ of stem, sometimes to the apex, rarely reddish. Leaves anisophyllous. Lateral leaves 1.9-6.3 x 0.6-2.4 mm, patent, basifixed, oblong, ovate-oblong or lanceolate, base biauriculate, the acroscopic side longer, auricles dentate to short-ciliate, margins serrate to entire, apex acute to cuneate, rarely obtuse, upper surface smooth, rarely with idioblasts (restricted to the margins). Axillary leaves similar to the lateral leaves, but 1.6-5.1 $\mathrm{x}$ 0.5-1.6 mm, ovate, lanceolate or elliptic. Dorsal leaves 1.5-4.3 x 0.6-2.1 mm, peltate, elliptic, rarely ovate, base auriculate externally and rounded internally, sometimes biauriculate with a larger external side, auricle dentate to short-ciliate, margins serrate, apex acuminate (sometimes appearing aristate in herbarium specimens), rarely acute, upper surface smooth, rarely with idioblasts, idioblasts inconspicuous, restricted to apex and margins. Strobilus to $19.6 \mathrm{~mm}$ long, with one basal megasporophyll followed by two microsporophylls, dorsal microsporophylls equal or shorter than ventral sporophylls; megasporangia and megasporophylls ca. two times longer and wider than microsporangia and microsporophylls. Dorsal sporophylls carinate, carina generally serrate, ovate-lanceolate, margins serrate. Ventral sporophylls carinate, carina generally serrate, ovate-lanceolate, margins serrate. Megaspores cream or white. Microspores cream.

Distribution and habitat: Widely distributed in Brazil (Amazonas, Pará, Ceará, Paraíba, Pernambuco, Acre, Bahia, Mato Grosso, Minas Gerais, Espírito Santo, Rio de Janeiro, São Paulo, Paraná, Santa Catarina and Rio Grande do Sul), occurring in the interior of forests in humid places, usually in slopes.

Selected specimens examined: BRAZIL. Minas Gerais: Açucena, 29/III/2009, T.E. Almeida et al. 1918 (BHCB); Araponga, Parque Estadual da Serra do Brigadeiro, 10/ VII/1999, A. Salino 4885 (BHCB); Dores de Guanhães, 14/VIII/2005, T.E. Almeida et al. 70 (BHCB); Januária, 24/V/1997, A. Salino 3038 (BHCB); Santa Rita de Jacutinga, 14/XI/2000, A. Salino et al. 5876 (BHCB).

Comments: Selaginella sulcata is easily identified by its articulate stem, with two vascular bundles, two auricles on the lateral leaves (the acroscopic side larger) and biauriculate axillary leaves. Some authors treat $S$. glaziovi Fée as a synonym of S. suavis (i.e. Alston et al. 1981; Hirai \& Prado 2000; Hassler \& Schmitt 2015); however, digital images of Glaziou 2244 revealed that $S$. glaziovi Fée can be a synonym of $S$. sulcata, as can be found under the comments of $S$. suavis.

18. Selaginella tenella (P. Beauv.) Spring, Bull. Acad. Roy. Sci. Brux. 10: 234. 1843. Diplostachium tenellum P. Beauv. Mag. Encycl. 9(5): 481. 1804. Lycopodium tenellum (P. Beauv.) Desv. ex Poir., Encycl. Suppl. 3: 553. 1814. Type: Porto Rico, Portorico, N.A. Desvaux s.n., ex herbarium Ventenat (neotype: P not seen, BM).

\section{Fig. 4D-G}

Stem erect to ascending, greenish to stramineous, to $12 \mathrm{~cm}$ long, 0.3-0.6 mm diam., stoloniferous, vascular bundle one; terminal branch 1.9-3.7 mm wide, with radicant apex. Rhizophores ventral, rarely axillary, present on the lower $1 / 2$, rarely above. Leaves anisophyllous. Lateral leaves $1.4-2.5 \times 0.5-1.1 \mathrm{~mm}$, patent to ascending, basifixed, oblong to ovate, base slightly rounded on the acroscopic side, margins entire to serrate, not hyaline to slightly hyaline, with elongate, translucent cells, apex acute to obtuse, upper surface smooth to slightly papillose, generally with idioblasts (these sometimes obscure). Axillary leaves similar to the lateral leaves, but oblong-elliptic to elliptic. Dorsal leaves 0.9-1.6 x 0.3-0.6 $\mathrm{mm}$, basifixed, elliptic, base slightly rounded, margins serrate to short-ciliate, hyaline to slightly hyaline, with elongate, translucent cells, apex long-aristate, margins serrate, arista more than $1 / 3$ of leaf, upper surface smooth to slightly papillate, generally with idioblasts (these sometimes obscure). Strobilus to $5.8 \mathrm{~mm}$ long, dorsal sporophylls longer than ventral sporophylls. Dorsal sporophylls carinate, carina generally serrate, long- to ovate-lanceolate, margins serrate to short-ciliate, hyaline, with elongate cells, upper surface with idioblasts (these 

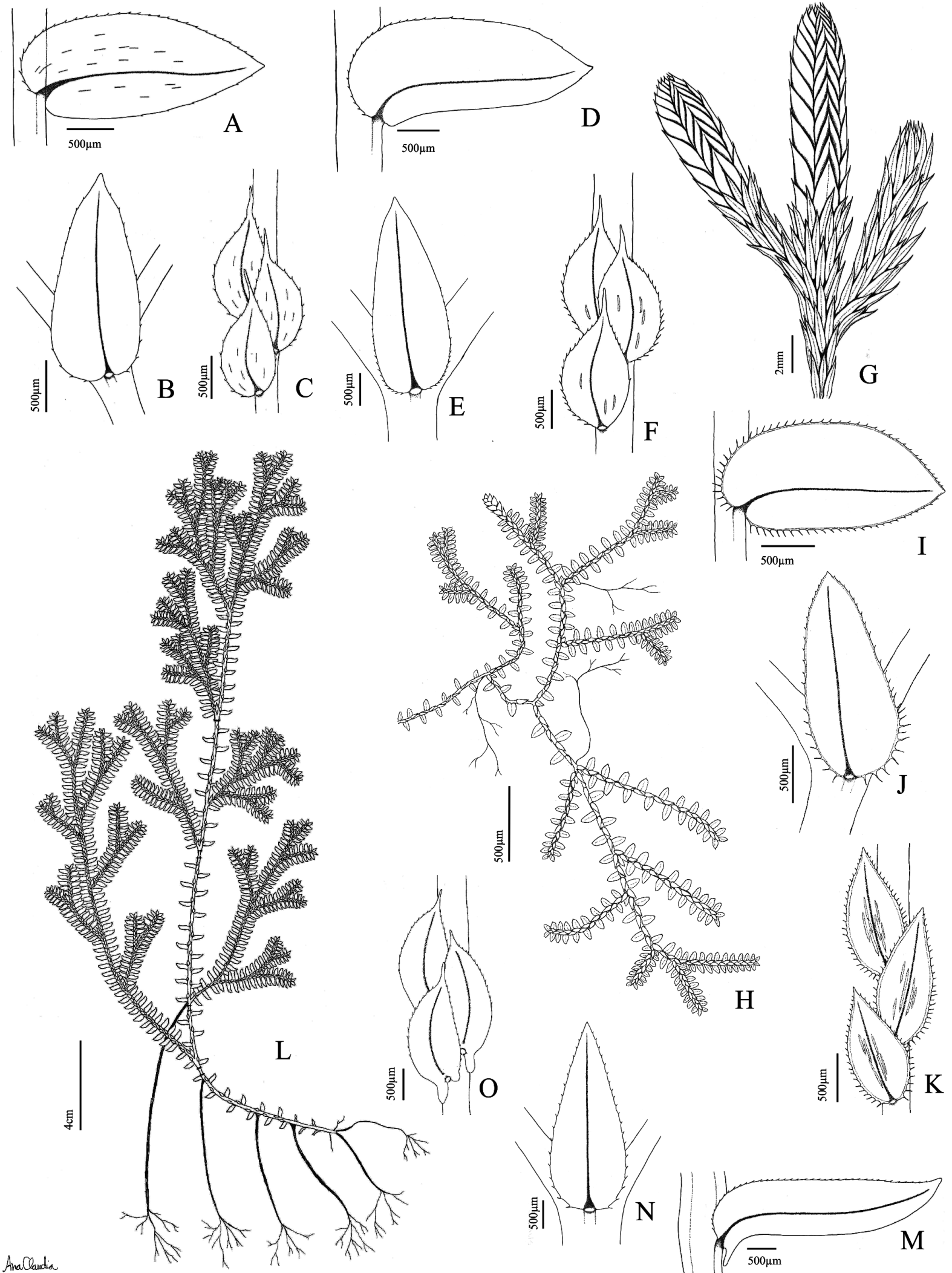

Anallaudia

Figure 3. A-C. Selaginella muscosa Spring (Almeida 110). A. Dorsal view of lateral leaf; B. Ventral view of axillary leaf; C. Dorsal view of dorsal leaves. D-F. Selaginella producta Baker (Salino 8328a). D. Ventral view of lateral leaf; E. Ventral view of axillary leaf; F. Dorsal view of dorsal leaves. G. Selaginella sellowii Hieron. (Salino 9404). G. View of branch and strobilus. H-K. Selaginella sematophylla Valdespino, G. Heringer \& Salino (Salino 14543). H. Habit; I. Ventral view of lateral leaf; J. Ventral view of axillary leaf; K. Dorsal view of dorsal leaves. L-O. Selaginella suavis (Spring) Spring (Almeida 1974). L. Habit; M. Ventral view of lateral leaf; N. Ventral view of axillary leaf; O. Dorsal view of dorsal leaves. 
sometimes obscure). Ventral sporophylls carinate, long- to ovate-lanceolate, margins serrate to short-ciliate, obscurely hyaline, with elongate cells. Megaspores white to cream yellowish. Microspores orangish.

Distribution and habitat: Brazil (Pará, Maranhão, Mato Grosso and Minas Gerais), terrestrial or rupicolous in the interior of forests and on limestone outcrops.

Selected specimens examined: BRAZIL. Minas Gerais: Inhapim, 30/V/2009, T.E. Almeida et al. 1974 (BHCB); Januária, 24/V/1997, A. Salino 3036 (BHCB); Idem, 20/ VII/1997, A. Salino 3248 (BHCB); Idem, 24/V/1997, A. Salino 3090 (BHCB); Rio Casca, 3/II/1998, A. Salino 3948 (BHCB); São José do Mantimento, 6/IX/2009, T.E. Almeida et al. 2097 (BHCB).

Comments: Selaginella tenella is cited here for the first time for the state of Minas Gerais. This species is characterized by its erect to ascending, stoloniferous habit, and apex that is generally radicant. Based on these characters it is easy to identify this species; however, specimens that lack a radicant apex require careful study. In this case the delicate leaves, the formation of large populations (usually represented by collections with numerous specimens), presence of idioblasts and dorsal sporophylls that are generally larger than the ventral sporophylls can be used to identify this species.

19. Selaginella tenuissima Fée, Crypt. vasc. Brésil 2: 98. 1873. Syntypes: Brazil, Rio de Janeiro, A.F.M. Glaziou 4499 (C no seen, B! [B200095602], K-image! [K000589061], P! [P00044826], P [P00573924]).

Selaginella papagaiensis Silveira forma $\alpha$ [alpha], Bol. Commiss. Geogr. Geol. Minas Geraes 5: 125. 1898. Syntypes: Brazil, Minas Gerais, In campis humidis in Serra do Papagaio, Minas, XI/1897, Silveira s.n. B! [B200120913], BM! (as Herbarium Silveira n. 154), R! (as Herbarium Silveira $n$. 154) [179579]; [Serra Negra, inter Lima Duarte et Rio Preto, H. Magalhães s.n. (n. 2603 in herb. Com. Geog. et Geol. Civitatis Minas Geraes)].

Selaginella papagaiensis Silveira forma $\beta$ [beta], Bol. Commiss. Geogr. Geol. Minas Geraes 5: 125. 1898. In campis humidis in Serra do Papagaio, Minas, Nov. 1897, Silveira s.n.: B-image! [B200120911], R! (as Herbarium Silveira n. 155) [179614].

\section{Fig. 4H-J}

Stem prostrate, greenish to stramineous, to $15 \mathrm{~cm}$ long, 0.3-0.9 mm diam., vascular bundle one; terminal branch 1.4-4.4 mm wide. Rhizophores ventral, rarely axillary or ventral and dorsal on the same bifurcation, present throughout stem. Leaves anisophyllous. Lateral leaves $1.2-2.3 \times 0.6-1.8 \mathrm{~mm}$, patent, rarely slightly ascending or reflexed, sometimes incurved, basifixed, widely elliptic to ovate, base rounded, margins entire, serrate or shortciliate, apex obtuse, upper surface smooth to slightly papillose. Axillary leaves similar to the lateral leaves, but 1.0-2.1 x 0.6-1.2 mm, oblong, rarely oblong-obovate, margins serrate, rarely short-ciliate. Dorsal leaves 0.8 $2.0 \times 0.5-1.5 \mathrm{~mm}$, basifixed, ovate to cordiform, base rounded to cordate, margins serrate to short-ciliate, not hyaline to rarely slightly hyaline, with elongate, translucent cells, apex aristate to long-attenuate, generally incurved, margins serrate, upper surface slightly papillose. Strobilus to $2.2 \mathrm{~mm}$ long, dorsal and ventral sporophylls equal in length. Dorsal sporophylls carinate, carina smooth to serrate at the apex, ovate-lanceolate, margins serrate, hyaline, with elongate cells. Ventral sporophylls carinate, ovate-lanceolate, margins serrate, obscurely hyaline, with elongate cells. Megaspores white. Microspores orangish.

Distribution and habitat: Southeastern and southern Brazil (Minas Gerais, Rio de Janeiro, São Paulo, Paraná, Santa Catarina and Rio Grande do Sul). Terrestrial or rupiculous, generally in humid environments.

Selected specimens examined: BRAZIL. Minas Gerais: Alto Caparaó, Parque Nacional do Caparaó, 18/IX/1988, L. Krieger 293 (CESJ) Itamonte, Parque Nacional do Itatiaia, 10/VII/2007, A. Salino et al. 12360 (BHCB); Moeda, 4/III/2006, G. Heringer et al. 35 (BHCB); Ouro Preto, 6/I/2007, G. Heringer et al. 148 (BHCB); São Gonçalo do Rio Preto, Parque Estadual do Rio Preto, 21/IV/2007, T.E. Almeida et al. 795 (BHCB).

Comments: Selaginella tenuissima is a delicate species that is characterized by its prostrate habit, lateral leaves with an obtuse to rounded apex, and oblong (rarely oblong-obovate) axillary leaves. This species differs from S. muscosa by the characters presented in the comments under S. muscosa.

20. Selaginella vestiens Baker, J. Bot., Lond. 21: 97. 1883. Type: Brazil, Goias, Morro de Canta Gallo, W.J. Burchell 7006 (holotype: K!; isotype: pro parte B!).

Selaginella erythrospora Silveira, Bol. Commiss. Geogr. Geol. Minas Geraes. 5: 126. 1898. Type: Brazil, Minas Gerais, São João Del Rei, Serra do Lenheiro, IV/1897, A.A. Silveira s.n.; n. 2383 in herb. Com. Geog. et Geol. Civitatis Minas Geraes (holotype: R! [as Herbarium Silveira n. 156, R 179582]; isotype: B!, BM! [as Herbarium Silveira n. 156, $\mathrm{R}$ 179582].

Selaginella fragillima Silveira, Bol. Commiss. Geogr. Geol. Minas Geraes. 5: 127. 1898. Type: Brazil, Minas Gerais, Serra de São José Del Rei, Aguas Santas, III/1898, A.A. Silveira s.n.; n. 2622 in herb. Com. Geog. et Geolog. Civitatis Minas Geraes (holotype: R! [as Herbarium Silveira n. 149]; isotype: B! [B200095193], P-image! [P01282490]).

\section{Fig. 4K-M}

Stem erect, greenish to stramineous, rarely prostrate in younger plants, to $9 \mathrm{~cm}$ long, $0.2-0.7 \mathrm{~mm}$ diam., stoloniferous, vascular bundle one; terminal branch $1.2-2.9 \mathrm{~mm}$ wide. Rhizophores obscurely ventral, on base of stem. Leaves isophyllous at base, becoming anisophyllous near first branch. Lateral leaves $1.2-2.2 \times 0.6-1.2 \mathrm{~mm}$, 


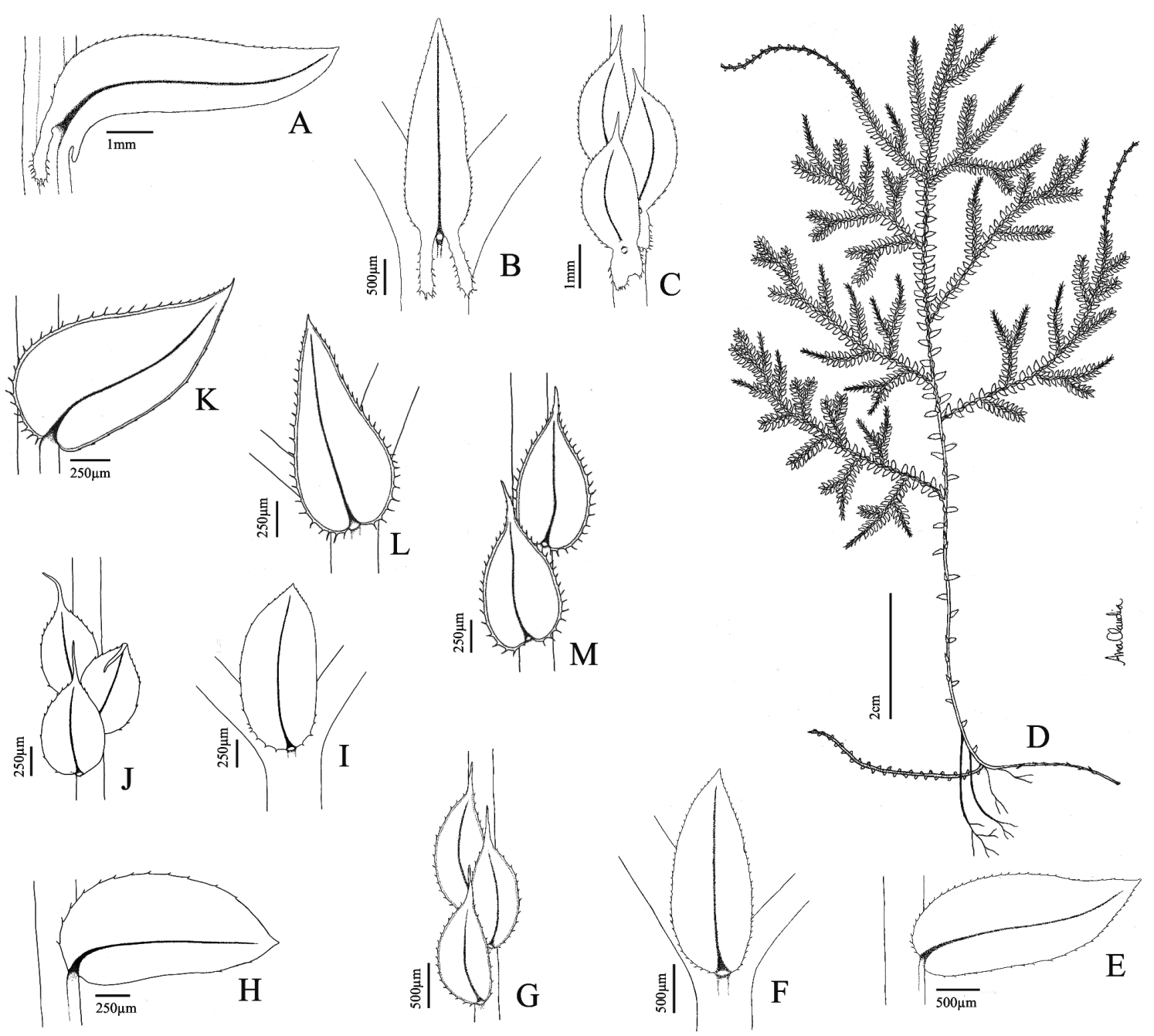

Figure 4. A-C. Selaginella sulcata (Desv. ex Poir.) Spring ex Mart. (Salino 4885). A. Ventral view of lateral leaf; B. Ventral view of axillary leaf; C. Dorsal view of dorsal leaves. D-G. Selaginella tenella (P. Beauv.) Spring (Almeida 1974). D. Habit; E. Ventral view of lateral leaf; F. Ventral view of axillary leaf; G. Dorsal view of dorsal leaf. H-J. Selaginella tenuissima Fée (Heringer 148). H. Vental view of lateral leaf; I. Ventral view of axillary leaf; J. Dorsal view of dorsal leaves. K-M. Selaginella vestiens Baker (Salino 8364). K. Ventral view of lateral leaves; L. Ventral view of axillary leaf; M. Dorsal view of dorsal leaves.

adpressed basally, becoming patent near first branch, sometimes incurved, basifixed, ovate-lanceolate, rarely widely lanceolate, base cordate, passing below stem on acroscopic side, margins serrate to ciliate, slightly hyaline, with elongate, translucent cells, apex acute, upper surface smooth to slightly rugose. Axillary leaves similar to the lateral, but lanceolate, base rounded, rarely slightly cordate on one side. Dorsal leaves 0.9-2.0 x 0.4-1.0 mm, basifixed, lanceolate to elliptic-lanceolate, base rounded to slightly rounded, margins ciliate to short-ciliate, hyaline, with elongate, translucent cells, apex acuminate to aristate, serrate on margins and dorsally, arista ca. $1 / 3$ of leaf, upper surface smooth to rugose. Strobilus to 7.3 $\mathrm{mm}$ long, dorsal sporophylls equal or longer than ventral sporophylls. Dorsal sporophylls carinate, carina serrate (less near apex), long- to ovate-lanceolate, margins serrate, hyaline, with elongate cells. Ventral sporophylls carinate, long- to ovate-lanceolate, margins serrate, ob- scurely hyaline, with elongate cells. Megaspores yellow. Microspores orangish.

Distribution and habitat: Brazil (Bahia, Goiás, Minas Gerais, Rio de Janeiro and São Paulo), growing on rocky outcrops or sandy soil where it is terrestrial or rupicolous. Selected specimens examined: BRAZIL. Minas Gerais: Buenópolis, Parque Nacional das Sempre Vivas, 19/ VI/2008, T.E. Almeida et al. 1371 (BHCB); Catas Altas, RPPN Santuário do Caraça, 26/IV/2009, R.S. Viveros et al. 86 (BHCB); Congonhas do Norte, 3/III/1998, J.R. Pirani et al. 4161 (SPF); São Gonçalo do Rio Preto, Parque Estadual do Rio Preto, 8/IV/2000, A. Salino et al. 5213 (BHCB); São João Del Rei, 18/II/1985, L. Krieger et al. s.n. (CESJ 20381).

Comments: Selaginella vestiens is characterized by its erect habit, with isophyllous leaves until near the first branch, presence of a stolon and lateral leaves with a cordate base (acroscopically). 


\section{Acknowledgments}

We thank Ana Claúdia Fernandes for the illustrations, Luiz Góes-Neto for the suggestions in the manuscript, the curators of the herbaria visited and that sent material, and the Programa de Pós-Graduação em Biologia Vegetal of the Universidade Federal de Minas Gerais. Salino and Heringer thank the CAPES for scholarship to Heringer, and to the CNPq for grants, as well as to the Fundação Grupo Boticário for financial support. Valdespino thanks the dean's office of the Faculty of Natural and Exact Sciences and Technology, and the Vice-President Office of Research and Graduate Programs of the University of Panama for the support.

\section{References}

Alston AHG. 1936. The Brazilian species of Selaginella. Feddes Repertorium 40: 303-319.

Alston AHG, Jermy AC, Rankin JM. 1981. The genus Selaginella in tropical South America. Bulletin of the British Museum (Natural History), Botany Series 9: 233-330.

Baker JG. 1883. A synopsis of the genus Selaginella. Journal of Botany 21: 1-5.

Banks JA. 2009. Selaginella and 400 million years of separation. Annual Review of Plant Biology 60: 223-238.

Bautista HP. 1974a. Duas espécies novas de Selaginella da Amazônia. Boletim do Museu Paraense Emílio Goeldi 45: 1-5.

Bautista HP. 1974b. Uma nova Selaginella (Pteridophyta) do T.F. Roraima. Acta Amazonica 4: 19-21.

Bautista HP, Berg ME, Paulo BC. 1975. Flora amazônica. I- Pteridófitas. Boletim do Museu Paraense Emílio Goeldi. Nova série: Botânica 48: 1-41.

Castellani ED, Freitas CA. 1992. Selagineláceas da Reserva Florestal Ducke (Manaus - AM). Acta Botanica Brasilica 6: 41-48.

Fée ALA. 1869. Cryptogames vasculaires du Brésil. Vol. I. Paris, Veuve Berger-Levrauuld \& Fils.

Fée ALA. 1873. Cryptogames vasculaires du Brésil. Vol. II. Paris, Veuve Berger-Levrauuld.

Fraile ME, Somers Jr. P, Moran RC. 1995. Selaginellaceae. In: Moran RC, Riba R. (eds.) Flora Mesoamericana. Vol. 1. Psilotaceae a Salviniaceae. Cuidad de México, Univercidad Nacional Autónoma de México. p. 22-42.

Góes-Neto LAA, Heringer G, Salino A. 2015. Selaginella salinoi (Selaginellaceae), a new species from Brazil. Phytotaxa 224: 291-295.

Hassler M, Schmitt B. 2015. Checklist of Ferns and Lycophytes of the World. https://worldplants.webarchiv.kit.edu/ferns/.17 Sep. 2015.

Hirai RY, Prado J. 2000. Selaginellaceae Willk. no Estado de São Paulo, Brasil. Revista Brasileira de Botânica 23: 313-339.

Hirai RY. 2007. Selaginella. In: Cavalcanti TB. (ed.) Flora do Distrito Federal, Brasil. Vol. VI. Brasília, Embrapa Recursos Genéticos e Biotecnologia p. 161-168.

Jermy AC. 1986. Subgeneric names in Selaginella. Fern Gazette 13: $117-118$.

Jermy AC. 1990. Selaginellaceae. In: Kramer KU, Green PS. (eds.) The families and genera of vascular plants. Berlin, Springer Verlag. p. 39-45.

Korall P, Kenrick P. 2002. Phylogenetic relationships in Selaginellaceae based on $r b c L$ sequences. American Journal of Botany 89: 506-517.

Korall P, Kenrick P. 2004. The phylogenetic history of Selaginellaceae based on DNA sequences from the plastid and nucleus: extreme substitution rates and rate heterogeneity. Molecular Phylogenetics and Evolution 31:852-64.
Korall P, Kenrick P, Therrien P. 1999. Phylogeny of Selaginellaceae: Evaluation of generic/subgeneric relationships based on $r b c L$ gene sequences. International Journal of Plant Sciences 160: 585-594.

Lellinger DB. 2002. A modern multilingual glossary for taxonomic pteridology. Pteridologia 3: 1-263.

Mickel JT, Smith AR, Valdespino IA. 2004. Selaginella. In: Mickel JT, Smith AR. (eds.) The pteridophytes of Mexico. New York, Memoirs of The New York Botanical Garden 88: 550-602. p. 39-45.

Mital PL. 1969. Epidermal studies in the genus Selaginella. Bulletin of the Botanical Survey of India 11: 150-160.

Prado J, Freitas, CAA. 2005. Flora da Reserva Ducke, Amazônia, Brasil: Pteridophyta-Selaginellaceae. Rodriguésia 56: 98-102.

Prado J, Hirai RY. 2008. Criptógamos do Parque Estadual das Fontes do Ipiranga, São Paulo, SP. Pteridophyta: 13. Lycopodiaceae e 20. Selaginellaceae. Hoehnea 35: 543-525.

Pryer KM, Schneider H, Smith AR, et al. 2001. Horsetails and ferns are a monophyletic group and the closest living relatives to seed plants. Nature 409: 618-621.

Pryer KM, Schuettpelz E, Wolf PG, Schneider H, Smith AR, Cranfill R. 2004. Phylogeny and evolution of ferns (monilophytes) with a focus on the early leptosporangiate divergences. American Journal of Botany 91: 1582-1598.

Rowe NP. 1988. A herbaceous lycophyte from the Lower Carboniferous Drybook Sandstone of the Forest of Dean, Glouscestershire. Palaeontology 31: 69-83.

Silveira AA. 1898. Novae species Lycopodiacearum civitatis Minas Geraes, Brazil. Boletim da Commissão Geográfica e Geológica do Estado de Minas Geraes 5: 117-145.

Silveira AA. 1908. Flora e serras mineiras. Belo Horizonte, Impressa Oficial.

Somers P. 1978. A systematic survey of the Articulatae series of the genus Selaginella and monographic treatment of the S. sulcata group (sensu str.). PhD Thesis, The University of Tennessee, USA.

Spring AF. 1840. Selaginella. In: Martius CFP, Eichler AG. (eds.) Flora Brasiliensis. Vol. I, pars II. Lipsiai apud Frid. Fleischer in Comm. Monachii. p.117-132.

Spring AF. 1849. Monographie de la famille des Lycopodiacées. Second partie. Mémoires Académie Royale de Belgique 24: 1-358.

Stearn WT. 1992. Botanical Latin. 4th. edn. New Hampshire, David \& Charles.

Thiers B. 2015. [continuously updated]. Index Herbariorum: A global directory of public herbaria and associated staff. New York Botanical Garden's Virtual Herbarium. http://sweetgum.nybg.org/ih/. 02 Jun. 2015.

Thomas BA. 2005. A reinvestigation of Selaginella species from the Asturian (Westphalian D) of the Zwickau coalfield, Germany and their assignment to the new sub-genus Hexaphyllum. Zeitschrift der Deutschen Gesellschaft für Geowissenschaften 156: 403-414.

Tryon RM, Stolze RG. 1994. Pteridophyta of Peru, Part VI, 22. Marsileaceae - 28. Isoetaceae. Fieldiana, botany n.s. 34: 66-88.

Tryon RM, Tryon AF. 1982. Ferns and allied plants, with special reference to tropical America. New York, Springer Verlag.

Valdespino IA. 1995. A monographic revision of Selaginella P. Beauv. subgenus Heterostachys Baker in Central and South America. $\mathrm{PhD}$ Thesis, The City University of New York, USA.

Valdespino IA, Heringer G, Salino A, Góes-Neto LAA., Ceballos J. 2015. Seven new species of Selaginella subg. Stachygynandrum (Selaginellaceae) from Brazil and new synonyms for the genus. Phytokeys 50: 61-99.

Valdespino IA, López C, Góes-Neto LAA. 2014. Additions to Cuban Selaginella (Selaginellaceae). Phytotaxa 184: 235-244.

Walton J, Alston AHG. 1938. Lycopodiinae. In. Verdoorn F. (ed.) Manual of Pteridology. The Hague, Nijhoff. p. 500-506.

Webster, TR. 1992. Developmental problems in Seleginella (Selaginellaceae) in an evolutionary context. Annals of the Missouri Botanical Garden 79: 632-647. 